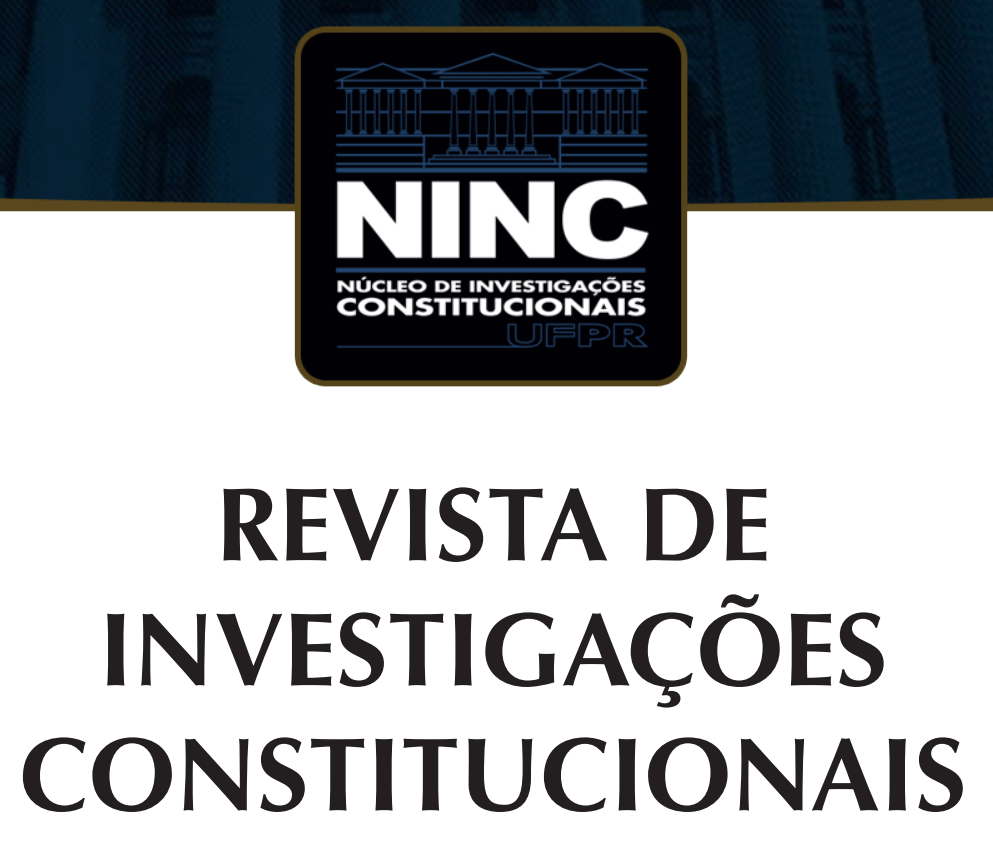

JOURNAL OF CONSTITUTIONAL RESEARCH

vol. 6 | n. 3 | setembro/dezembro 2019 | ISSN 2359-5639 | Periodicidade quadrimestral Curitiba | Núcleo de Investigações Constitucionais da UFPR | www.ninc.com.br 


\title{
Hierarquia supraconstitucional relativa dos tratados internacionais de direitos humanos
}

\section{Relative and supraconstitutional hierarchy of international human rights treaties}

\author{
FELIPE KLEIN GUSSOLI 1,* \\ ' Instituto de Direito Romeu Felipe Bacellar (Curitiba-PR, Brasil) \\ gussoli@hotmail.com \\ https://orcid.org/0000-0002-2585-6548
}

Recebido/Received: 24.05 .2019 / May $24^{\text {th }}, 2019$ Aprovado/Approved: 16.12.2019 / December $16^{\text {th }}, 2019$

Resumo

$\mathrm{O}$ artigo parte das classificações mais frequentes sobre a hierarquia dos tratados internacionais de direitos humanos no ordenamento jurídico para diante delas sugerir o reconhecimento do status hierárquico supraconstitucional relativo das convenções internacionais daquela natureza. A proposta afasta-se das posições santificadoras da soberania constitucional como único horizonte viável no plano jurídico contemporâneo. Reposiciona, assim, o discurso da força normativa da Constituição e demonstra a emergência de um paradigma jurídico universalista em que a própria Constituição Federal de 1988 assentou a relativização de suas normas em favor de instrumentos jurídicos internacionais. A partir de uma perspectiva dogmática, aliada ao princípio pro persona do Direito Internacional dos Direitos Humanos, a pesquisa busca acima de tudo contribuir para a rediscussão do posicionamento atual do Supremo Tribunal Federal

\section{Abstract}

The article starts from the most frequent classifications on the hierarchy of the international human rights treaties in the juridical order, therefor to suggest the recognition of the relative and supraconstitutional hierarchical status of the international conventions of human rights. The proposal departs from the sanctifying positions of constitutional sovereignty as the only viable horizon in the contemporary juridical plane. It thus replaces the discourse of the normative force of the Constitution and demonstrates the emergence of a universalist legal paradigm in which the Brazilian Federal Constitution of 1988 itself was based on the relativization of its norms in favor of international legal instruments. From a dogmatic perspective, and form the principle pro persona of International Human Rights Law, the research seeks above all to contribute to the re-discussion of the current position of the Brazilian Federal Supreme Court on the supralegal hierarchy of the treaties, as well as to initiate a

Como citar esse artigo/How to cite this article: GUSSOLI, Felipe Klein. Hierarquia supraconstitucional relativa dos tratados internacionais de direitos humanos. Revista de Investigações Constitucionais, Curitiba, vol. 6, n. 3, p. 703-747, set./dez. 2019. DOI: $10.5380 /$ rinc.v6i3.67058.

" Coordenador Adjunto e Professor do Curso de Especialização em Direito Administrativo do Instituto de Direito Romeu Felipe Bacellar (Curitiba-PR, Brasil). Mestre em Direito Econômico e Desenvolvimento pela Pontifícia Universidade Católica do Paraná. Bacharel em Direito pela Universidade Federal do Paraná. Professor do Curso de Especialização em Licitações e Contratos Administrativos da Pontifícia Universidade Católica do Paraná. Pesquisador do NUPED - Núcleo de Pesquisas em Políticas Públicas e Desenvolvimento Humano da PUCPR. Advogado em Curitiba-PR. E-mail: gussoli@hotmail.com. 
acerca da hierarquia supralegal dos tratados, bem como iniciar um diálogo com as teorias normativas heterárquicas em busca da formulação de critérios práticos para resolução de conflitos pelos julgadores.

Palavras-chave: supraconstitucionalidade; controle de convencionalidade; tratado internacional de direitos humanos; hierarquia dos tratados internacionais; soberania. dialogue with the heterarchical normative theories in search of the formulation of practical criteria for conflict resolution by the judges.

Keywords: supraconstitutionality; conventionality control; international human rights treaty; hierarchy of international treaties; sovereignty.

\section{SUMÁRIO}

1. Introdução; 2. Estado Constitucional e Convencional de Direito: o paradigma jurídico universalista;

3. Direito Internacional dos Direitos Humanos e força normativa dos tratados incorporados no Direito brasileiro; 4. Hierarquia supraconstitucional dos tratados de direitos humanos admitida pela Constituição brasileira; 4.1. Hierarquia legal dos tratados internacionais de direitos humanos; 4.2. Hierarquia supralegal dos tratados internacionais de direitos humanos: posição atual do Supremo Tribunal Federal; 4.3. Hierarquia constitucional dos tratados internacionais de direitos humanos; 4.4. Hierarquia Supraconstitucional dos tratados internacionais de direitos humanos; 5. Relativização do critério hierárquico de ordenação das normas: hierarquia supraconstitucional a priori dos tratados internacionais de direitos humanos; 6. Conclusão; 7. Referências.

\section{INTRODUÇÃO}

O presente estudo busca demonstrar as diferentes correntes sobre a hierarquia que os tratados internacionais de direitos humanos possuem na ordem jurídica a partir da interpretação das normas constitucionais sobre a matéria. E a partir disso, sugerir quais os caminhos que melhor se adaptam ao paradigma convencional do Direito global vivenciado no século XXI.

O objetivo central é problematizar os critérios utilizados pelo Supremo Tribunal Federal ao assentar a mera supralegalidade das Convenções internacionais incorporadas na ordem jurídica brasileira com base na supremacia irrestrita da Constituição. Apesar dos rompantes nacionalistas mais recentes no cenário brasileiro (e mundial), não é mais sustentável a defesa de uma soberania irrestrita na esfera das relações internacionais e das relações jurídicas globais. A existência de múltiplas ordens normativas, várias delas reconhecidas expressamente pelo Direito interno, precisa encarar como realidade imutável a sobreposição de princípios, regras e decisões. A formulação de um paradigma centralizador do humano e da natureza ${ }^{1}$ nessa rede ou cadeia de nor-

\footnotetext{
1 Os tratados de proteção do meio ambiente estão entre aqueles classificados como de direitos humanos. O ordenamento jurídico convencional contempla o respeito pelos direitos humanos e pelo meio ambiente (SANTOFIMIO GAMBOA, Jaime Orlando. El concepto de convencionalidad: vicisitudes para su construcción sustancial en el sistema interamericano de derechos humanos. Ideas fuerza rectoras. Madrid, 2016. $638 \mathrm{f}$. Tese pós-doutoral. Universidad Carlos III de Madrid; Universidad Externado de Colombia. p. 345).
} 
mas fortalece o privilégio do Direito Internacional dos Direitos Humanos no cenário mundial.

Assim, com a consciência da cada vez mais veloz ruptura de critérios hierárquicos rígidos na relação entre as normas jurídicas vigentes no tempo e espaço mundial, após demonstrar as diversas correntes em oposição, propõe-se a adoção da hierarquia supraconstitucional a priori de todos os tratados de direitos humanos incorporados, o que tem fundamento no próprio sistema constitucional brasileiro.

\section{ESTADO CONSTITUCIONAL E CONVENCIONAL DE DIREITO: O PARADIGMA JURÍDICO UNIVERSALISTA}

O pressuposto da presente pesquisa é o de que vigora no Brasil o paradigma jurídico universalista, ${ }^{2}$ cujo centro de irradiação são os direitos humanos. Desta forma, o pressuposto deste estudo é o reconhecimento de que o Brasil adota um modelo de Estado Constitucional e Convencional de Direito. ${ }^{3}$ O Século XXI tem como marca a quebra do paradigma do Direito estadualista. Vive-se hoje o paradigma pós-estadualista ou pluralista, em que a produção normativa estatal exclusiva dá lugar à múltiplas fontes fabricantes de regras. ${ }^{4}$ Neste paradigma a soberania está inquestionavelmente relativizada. O discurso da soberania atualmente é "frágil". Entre as diversas razões para

\footnotetext{
2 Para uma abordagem histórica da atual fase que pode ser chamada de "constitucionalismo transnacional" (sinônimo de transconstitucionalismo), no qual rompe-se o padrão centralizado de poder e soberania e o Estado se sujeita à normativa internacional e não só às suas próprias leis, cf. TEIXEIRA, Anderson Vichikesnki. Constitucionalismo transnacional: por uma compreensão pluriversalista do Estado constitucional. Revista de Investigações Constitucionais, Curitiba, v. 3, n. 3, p. 141-166, set./dez. 2016.
}

3 O ordenamento jurídico convencional é aquele "derivado do consenso internacional em matéria de direitos humanos, o qual pelo simples pertencimento de um Estado à comunidade de nações, busca acima de tudo cimentar a paz, a justiça social e a consolidação de estandartes de normalidade que garantam às pessoas de todos os Estados partes, instituições fortes, plenamente respeitosas dos direitos humanos, (subjetivos e coletivo), mediante ordens constitucionais e legais que afirmem a ideia material de um Estado social e democrático de direito". (SANTOFIMIO GAMBOA, Jaime Orlando. El concepto de convencionalidad... Op. Cit., p. 345).

4 "Mas, a partir dos finais do sec. XVIII, a opinião mais corrente, embora não única, era a de que essa legitimidade dos Estados para impor normas aos cidadãos resultava de este ser o produto da vontade dos mesmos cidadãos, expressa pelos órgãos que oficialmente os representavam (em primeiro lugar, pelos parlamentos, em quem residia, por isso, o poder de fazer as leias que compunham o direito do Estado). (...) Hoje, tudo se tornou menos nítido e mais complexo. Ao Estado contrapõe-se uma sociedade que parece produzir normas diretamente, sem necessitar da mediação oficial; à unidade do Estado contrapõe-se a dispersão de centros de poder normativo; às Nações, distintas e isoladas, contrapõe-se a 'sociedade global' de todas as nações, ultrapassando fronteiras dos Estados e pouco atenta ao recorte oficial das fronteiras; à unidade de cada um dos vários direitos, contrapõem-se direitos com diversos centros autónomos produtores de normas, desprovidos de coerência, sobrepostos, combinando normas de validade apenas local com outras que valem a um nível translocal, global. O Estado tende a deixar de ser considerado quer como a origem única do direito quer como a fonte da sua legitimação última". (HESPANHA, Antonio Manuel. Pluralismo jurídico e direito democrático. São Paulo: Annablume, 2013. p. 18)

5 SANTOS, Gustavo Ferreira; TEIXEIRA, João Paulo Allain. Diálogo entre tribunais e proteção de direitos humanos: dificuldades e perspectivas. A\&C - Revista de Direito Administrativo \& Constitucional, Belo Horizonte, a. 16, n. 66, p. 267-282, out./dez. 2016. p. 280. 
tanto, aponta-se aqui a globalização e as próprias Constituições que reconhecem o papel de destaque dos tratados e tribunais internacionais na superação da lógica estadocêntrica. ${ }^{6}$ A estadualidade enfrenta crise. Sem que a importância do Estado seja reduzida a zero, ocorre um processo de ressignificação da soberania, distribuição consensual de competências a órgãos internacionais, supranacionais ou transnacionais e expansão da relevância de Cortes judiciais internacionais. A distinção absoluta entre ordens jurídicas interna e externa enfrenta "diluição", e cada vez mais os Poderes estatais se veem obrigados a normas procedimentais e materiais de origem internacional. ${ }^{7}$

Entre as consequências do reconhecimento de um Direito que já não é mais exclusivamente produto do Parlamento ${ }^{8}$ está o fato de que a "globalização (sobretudo dos negócios, mas não apenas essa) apontaria forçosamente para uma ordem jurídica supranacional, tendencialmente global". ${ }^{9}$ Nessa ordem, o respeito à normativa internacional é o preço de participar da sociedade de Nações num mundo de isolamento impossível ou, no mínimo, insustentável. ${ }^{10}$

A estrutura normativa desse modelo de Estado de Direito Internacionalista ${ }^{11}$ ou Convencional contempla, além da Constituição e leis inferiores, também os tratados internacionais. Eles são parte essencial da regulamentação da ordem jurídica mundial, para a qual soluções locais não são suficientes para o enfrentamento de problemas globais. ${ }^{12}$ Por isso não é de nada estranho que a lei interna conviva com as convenções

6 BOGDANDY, Armin von. Ius Constitucionale Commune na América Latina. Uma reflexão sobre um constitucionalismo transformador. Revista de Direito Administrativo, Rio de Janeiro, v. 269, p. 33-66, maio/ago. 2015. p. 37-38.

7 TORELLY, Marcelo. Governança transversal dos direitos fundamentais. Rio de Janeiro: Lumen Juris, 2016. p. 78-91.

8 "Conhecer o direito, na atualidade, significa conhecer todas as suas fontes, que são (a) regramento abaixo das leis (resoluções, decretos, portarias etc.); (b) leis e códigos; (c) Constituição e jurisprudência interna; (d) tratados internacionais, especialmente os que versam sobre direitos humanos, e jurisprudência internacional; (e) direito universal". O jus cogens internacional está inserto no item "e" do Direito universal. (GOMES, Luiz Flávio; MAZZUOLI, Valerio de Oliveira. Direito Supraconstitucional: do absolutismo ao Estado Constitucional e Humanista de Direito. 2. ed. São Paulo: Revista dos Tribunais, 2013. p. 156).

9 HESPANHA, Antonio Manuel. Pluralismo jurídico... Op. Cit., p. 25.

10 GORDILLO, Agustín Alberto et al. Derechos humanos. 6. ed. Buenos Aires: Fundación de Derecho Administrativo, 2007. p. Il-14.

11 O Estado de Direito Internacionalista é uma fase classificatória do Estado de Direito proposta por Luiz Flávio Gomes e Valerio de Oliveira Mazzuoli. Ela se caracteriza pela ampla proteção conferida aos direitos humanos e nasceu junto com o Estado de Direito Constitucional, mais precisamente com a Carta da ONU de 1945, com a Declaração Universal dos Direitos do Homem de 1948 e os Pactos Internacionais dos Direitos Políticos e Civis e Direitos Econômicos, Sociais e Culturais de 1966. Após a fase internacionalista os autores defendem a emergência do paradigma universalista do Estado de Direito, ainda em construção, na qual prevalecem as normas supraconstitucionais, das quais é exemplo o Tratado de Roma instituidor do Tribunal Penal Internacional, em 1998. A classificação dos autores ajuda compreender as transformações da ordem jurídica internacional ao longo dos séculos. No entanto é evolucionista, passível por isso de críticas. Para detalhes cf. GOMES, Luiz Flávio; MAZZUOLI, Valerio de Oliveira. Direito Supraconstitucional... Op. Cit.

12 "Não podemos enfrentar os problemas da globalização do Planeta (espetaculares aumentos dos preços dos alimentos, energia nuclear, aquecimento climático, fluxos incontrolados de imigrantes, crise financeira 
produzidas no âmbito internacional, tal como instituições de natureza internacional convivem com as estruturas de organização estatal internas. ${ }^{13}$

Entre as espécies de tratados internacionais ${ }^{14}$ está aquela que protege direitos humanos. A tendência mundial é a formação de um constitucionalismo que transita de "documentos legislados nacionalmente para pactos construídos negocialmente em escala internacional sob o formato de tratados, como é o caso dos tratados internacionais de direitos humanos". ${ }^{15} \mathrm{~A}$ importância desses tratados aloca-se na relevância da proteção do ser humano, finalidade precípua do Direito. ${ }^{16} \mathrm{~A}$ finalidade de existência do Estado é propiciar o bem comum entre os seres humanos e garantir-lhes a vida digna, objetivo que põe em xeque o estadocentrismo. ${ }^{17}$

Ganha destaque, por isso, o ramo do Direito Internacional dos Direitos Humanos, no qual são relevantes os tratados e decisões de Cortes internacionais de direitos humanos. ${ }^{18}$ Todos os atos do Poder Público devem estar de acordo com a lei e a Constituição, mas também conforme a tratados internacionais de direitos humanos vigentes. ${ }^{19}$ Na realidade, a superação da exclusividade da legalidade estrita como parâmetro

mundial etc.) somente com os instrumentos, o direito as Justiças nacionais ou regionais. (...) Na questão do tráfico de drogas, por exemplo, pouco vale a atuação de um só país (ainda que sua iniciativa seja adequada). Problemas mundiais requerem um controle, um Direito e uma Justiça globais, a exemplo também dos inúmeros problemas ambientais pelos quais tem passado o nosso Planeta". (Idem, p. 149-150).

13 GANHO, Luciano Giambarresi; BRANDT, Rafael Weiss. Organização política regional na América-Latina: necessidade específica ou escolha caprichosa. Revista de Direito Econômico e Socioambiental, Curitiba, v. 5, n. 2, p. 113-135, jul./dez. 2014. p. 126.

14 Os tratados podem ser divididos em tratados internacionais comuns e tratados internacionais de direitos humanos. Na categoria dos tratados comuns estão os tratados mercantis, territoriais e de cooperação, por exemplo. Esses últimos, segundo o Supremo Tribunal Federal, têm valor legal, excepcionados os de Direito Tributário, com valor supralegal por disposição do Código Tributário Nacional. (MAZZUOLI, Valerio; GOMES, Luiz Flávio. Tratados internacionais: valor legal, supralegal, constitucional ou supraconstitucional? Revista de Direito, v. 12, n. 15, p. 7-20, 2009. p. 8-9).

15 VIEIRA, Gustavo Oliveira; MORAIS, José Luis Bolzan de. A internacionalização do Direito a partir dos diretos humanos - reflexões iniciais para o futuro do constitucionalismo. Revista de Estudos Constitucionais, Hermenêutica e Teoria do Direito (RECHTD), São Leopoldo, v. 4, n. 2, p. 175-184, jul./dez. 2012. p. 183.

16 "O agir estatal e o agir do cidadão em face do Estado e dos seus semelhantes, não pode perder de vista - mormente na tratativa de um tema dessa importância - a base antropológica comum que deflui da Constituição: o princípio da dignidade do ser humano, principal justificativa para a existência de qualquer norma". (BACELLAR FILHO, Romeu Felipe. Reflexões sobre Direito Administrativo. Belo Horizonte: Fórum, 2009. p. 15).

17 TRINDADE, Antônio Augusto Cançado. A humanização do Direito Internacional. Belo Horizonte: Del Rey, 2006. p. 126.

18 GOMES, Luiz Flávio; MAZZUOLI, Valerio de Oliveira. Direito Supraconstitucional... Op. Cit., p. 84.

19 "Da mesma forma, os atos administrativos, que até pouco tempo eram dotados de mera legalidade e que, a muito custo, passaram a ser objeto de análise (administrativa e jurisdicional) de constitucionalidade (em virtude do recente fenômeno da constitucionalização do direito administrativo, devem ser compatibilizados às normas convencionais, que estão abrangidas pelo conteúdo do princípio da juridicidade". (LEAL, Mônia Clarissa Henning; ALVES, Felipe Dalenogare. O controle de convencionalidade e o Judiciário brasileiro: a sua aplicação pelo Tribunal Superior do Trabalho como forma de proteger a dignidade da mão-de-obra (vedação de terceirização de atividade-fim) no case Carneiro Távora v. Telemar Norte Leste e Conta. Revista de Investigações Constitucionais, Curitiba, v. 4, n.1, p. 109-129, jan./abr. 2017. p. 113). 
único de aferição da validade dos comportamentos estatais tem lugar após a Segunda Guerra Mundial, momento em que ficou claro "que a proteção dos direitos humanos não pode ser tida como parte do domínio reservado de um Estado, pois as falhas na proteção local tinham possibilitado o terror nazista". ${ }^{20}$

\section{DIREITO INTERNACIONAL DOS DIREITOS HUMANOS E FOR- ÇA NORMATIVA DOS TRATADOS INCORPORADOS NO DIREITO BRASILEIRO}

Após o fim da Segunda Guerra Mundial, a Declaração Universal dos Direitos Humanos de 1948 inaugura a concepção contemporânea de direitos humanos. A segunda metade do século XX consolidou a passagem do Direito Internacional Público Clássico para o Direito Internacional dos Direitos Humanos. Há nessa passagem a substituição do paradigma da soberania estatal absoluta pelo paradigma humanista no Direito Internacional. A quebra da soberania absoluta foi reconhecida tanto no plano interno quanto no plano externo. Não estava mais autorizado ao Estado regular como bem entendesse a relação que tinha com seus cidadãos, nem mesmo dispor da força militar para atingir seus objetivos na arena internacional. ${ }^{21}$

Radica nesse período o nascedouro do Direito Internacional dos Direitos Humanos, ramo responsável pelo estudo e sistematização desses direitos caracterizados por serem "uma unidade indivisível, interdependente e inter-relacionada, capaz de conjugar o catálogo de direitos civis e políticos com o catálogo de direitos sociais, econômicos e culturais".22

A autonomia do Direito Internacional dos Direitos Humanos se sedimentou a partir de então com os Pactos dos Direitos Civis e Políticos e dos Direitos Econômicos, Sociais e Culturais de 1966, e posteriormente com as Conferências Mundiais de Direitos Humanos de Teerã (1968) e Viena (1993). ${ }^{23} \mathrm{~A}$ disciplina se destaca pela importância que concede à vítima de violações a direitos humanos. Mas, diferentemente do que o senso comum midiático faz parecer, os direitos humanos não estão voltados à proteção unilateral dos acusados em processos penais, embora estes sejam também categorizados como vítima quando algum de seus direitos convencionais forem violados. ${ }^{24}$ Os direitos humanos são aqueles essenciais à dignidade da pessoa humana ${ }^{25}$, do quais ninguém

20 RAMOS, André de Carvalho. Curso de Direitos Humanos. 2. ed. São Paulo: Saraiva, 2015. p. 90.

21 SILVA, Caíque Tomaz Leite da. Do realismo à constitucionalização do direito internacional. Revista do Direito Público, Londrina, v. 9, n. 1, p.135-162, jan./abr. 2014.

22 PIOVESAN, Flávia. Direitos humanos e Justiça Internacional. 5. ed. São Paulo: Saraiva, 2014. p. 47.

23 TRINDADE, Antônio Augusto Cançado. Tratado de Direito Internacional dos Direitos Humanos. v. I. 2. ed. Porto Alegre: Sergio Antonio Fabris Editor, 2003. p. 37.

24 GOMES, Luiz Flávio; MAZZUOLI, Valerio de Oliveira. Direito Supraconstitucional... Op. Cit., p. 92-93.

25 RAMOS, André de Carvalho. Curso... Op. Cit., p. 50. 
pode abrir mão enquanto detentores da qualidade que os torna humanos. Todos se beneficiam dos direitos humanos, sem os quais a existência digna estaria ameaçada por falta de limites à atuação estatal e por inexistência de deveres positivos dirigidos à igualdade material e ao desenvolvimento.

Antônio Augusto Cançado Trindade posiciona a fonte material do Direito Internacional dos Direitos Humanos na consciência jurídica universal, defensora da primazia protetiva do ser humano frente ao ente estatal abstrato. A disciplina conta com normas internacionais oriundas do sistema global e dos sistemas regionais de proteção, as quais inclusive preveem mecanismos de controle. ${ }^{26} \mathbf{A}$ nota distintiva desse ramo do Direito Internacional é o destaque que reconhece à posição do ser humano em suas relações em face do Estado. O Direito Internacional dos Direitos Humanos preocupa-se com os direitos da pessoa humana, o que o difere do Direito Internacional Público centrado na regulação das relações estatais. ${ }^{27}$

Os tratados internacionais de direitos humanos devem ser estudados, lidos, interpretados e aplicados segundo a lógica exposta do Direito Internacional dos Direitos Humanos, cujos pilares são a centralidade da pessoa humana e a cooperação entre os povos em torno da paz. ${ }^{28} \mathrm{~A}$ Constituição brasileira de 1988 assim reconhece quando em seu art. $4^{\circ}$, II determina que a República Federativa do Brasil seja regida em suas relações internacionais pela "prevalência dos direitos humanos". ${ }^{29} \mathbf{O}$ dispositivo é inovador na história brasileira. Ao positivá-lo, o Constituinte originário "está ao mesmo tempo reconhecendo a existência de limites e condicionamentos à noção de soberania estatal".30

Diversas Constituições latino-americanas reconheceram a partir do final dos anos 80 a força normativa dos tratados de direitos humanos, ${ }^{31}$ o que era parte de uma corrente elogiável de expansão de direitos fundamentais e fortalecimento de instituições de garantia. ${ }^{32}$ Entre elas, as Constituições do Chile, Peru, Venezuela, Equador, Bo-

26 TRINDADE, Antônio Augusto Cançado. Tratado de Direito... Op. Cit., p. 39.

27 PIOVESAN, Flávia. Direitos humanos e o Direito Constitucional internacional. 15. ed. São Paulo: Saraiva, 2015. p. 81.

28 MOREIRA, Thiago Oliveira. A aplicação dos tratados internacionais de direitos humanos pela jurisdição brasileira. Natal: EDUFRN, 2015. p. 54.

29 (Constituição Federal) Art. 40 A República Federativa do Brasil rege-se nas suas relações internacionais pelos seguintes princípios: II - prevalência dos direitos humanos.

30 PIOVESAN, Flávia. Direitos humanos e o Direito... Op. Cit., p. 107.

31 SALAZAR MUÑOZ, Rodrigo. Los derechos humanos en México: un reto impostergable. Revista de Investigações Constitucionais, Curitiba, vol. 3, n. 1, p. 145-168, jan./abr. 2016.

32 Sobre alguns dos impactos dessa expansão dos direitos humanos no Direito Público argentino, ver: GATTI, Franco. La doctrina del "margen de apreciación nacional" y la Administración Pública: horizontes y limitaciones del control de convencionalidad. Revista Eurolatinoamericana de Derecho Administrativo, Santa Fe, vol. 3, n. 1, p. 19-32, ene./jun. 2016. ALIANAK, Raquel Cynthia. El renovado Derecho Administrativo, a la luz del control de convencionalidad. Revista Eurolatinoamericana de Derecho Administrativo, Santa Fe, vol. 2, n. 1, 
lívia e Colômbia. ${ }^{33}$ No Brasil, a mesma Constituição que garante a primazia dos direitos humanos nas relações internacionais regulamenta a recepção dos tratados internacionais, resumida em quatro fases: (i) assinatura; (ii) aprovação congressual; (iii) ratificação; (iv) incorporação. ${ }^{34}$ Segundo a posição acolhida pelo Supremo Tribunal Federal, é o Decreto Presidencial que "inova a ordem jurídica brasileira, tornando válido o tratado no plano interno".35 Desde o julgamento do Agravo Regimental em Carta Rogatória n. 8.279-4-Argentina, o Plenário da Corte definiu a necessidade de promulgação pelo Presidente da República seguida de publicação do decreto executivo em diário oficial para dar início à vigência dos tratados no plano interno. ${ }^{36} \mathrm{~A}$ publicação em diário torna o tratado conhecido, diferentemente da mera ratificação, cujo momento em acontece não é de fácil conhecimento. É dizer, a publicação torna o tratado conhecido em todo o território nacional, enquanto a ratificação pode passar desapercebida. Embora existam críticas e divergências entre os próprios Ministros a respeito do momento exato da incorporação ${ }^{37}$, a posição majoritária no Brasil é a que considera a publicação do texto do tratado em diário oficial na forma de decreto executivo o momento em que os tratados internacionais de qualquer espécie, inclusive os de direitos humanos, ganham força normativa vinculante em face de todos os Poderes de Estado e dos particulares. ${ }^{38}$ Os efeitos internos do tratado dependerão, em todo caso e independentemente da publicação do decreto presidencial, do início da vigência do pacto no plano internacional. ${ }^{39}$

p. 283-300, ene./jun. 2015; CASSAGNE, Juan Carlos. Los nuevos derechos y garantías. Revista de Investigações Constitucionais, Curitiba, vol. 3, n. 1, p. 59-108, jan./abr. 2016.

33 HERNÁNDEZ, Jesús M. Casal. El constitucionalismo latinoamericano y la oleada de reformas constitucionales en la región andina. Rechtsgeschichte, Munique, v. 16, p. 212-241, 2010. p. 219-220.

34 Art. 49, I e 84, VIII da Constituição Federal de 1988.

35 RAMOS, André de Carvalho. Curso... Op. Cit., p. 384.

36 "A recepção dos tratados internacionais em geral e dos acordos celebrados pelo Brasil no âmbito do MERCOSUL depende, para efeito de sua ulterior execução no plano interno, de uma sucessão causal e ordenada de atos revestidos de caráter político-jurídico, assim definidos: (a) aprovação, pelo Congresso Nacional, mediante decreto legislativo, de tais convenções; (b) ratificação desses atos internacionais, pelo Chefe de Estado, mediante depósito do respectivo instrumento; (c) promulgação de tais acordos ou tratados, pelo Presidente da República, mediante decreto, em ordem a viabilizar a produção dos seguintes efeitos básicos, essenciais à sua vigência doméstica: (1) publicação oficial do texto do tratado e (2) executoriedade do ato de direito internacional público, que passa, então - e somente então - a vincular e a obrigar no plano do direito positivo interno". (BRASIL, Supremo Tribunal Federal. Agravo Regimental em Carta Rogatória n. 8.279-4-Argentina. Tribunal Pleno. Relator Min. Celso de Mello. Julgado em 17/06/1998. Publicado em 10/08/2000).

37 Há tese bastante sedutora que acolhe como data de início da vigência do tratado o momento do depósito do instrumento de ratificação. Tal posicionamento foi defendido pelo Min. Luiz Edson Fachin no Processo de Registro de Candidatura n 0600903-50.2018.6.00.0000-TSE, no qual Luiz Inácio Lula da Silva buscava candidatar-se à presidência, não obstante a suspensão de seus direitos políticos. O voto contém considerações importantes sobre o início da vigência dos tratados, defendendo que basta a aprovação congressual por Decreto Legislativo para garantir publicidade à normativa.

38 FRAGA, Mirtô. A obrigatoriedade do tratado na ordem interna. Revista de Informação Legislativa, Brasília, a. 41, n. 162, p. 311-328, abr./jun. 2004. p. 317.

39 MOREIRA, Thiago Oliveira. A aplicação dos tratados... Op. Cit., p. 155. 
Uma vez em vigor no plano internacional, a partir da publicação do texto do tratado em diário oficial, momento em que se garante ampla publicidade à norma de origem internacional, é que se pode falar em vigência e em incidência do art. $5^{\circ}, \S 1^{\circ} \mathrm{da}$ Constituição, garantia da autoaplicabilidade. Há quem sustente a existência de parâmetros para a autoaplicabilidade, condicionado sua incidência imediata apenas quando: (a) dele "deriva diretamente um direito ou uma pretensão a favor do indivíduo que comparece a um juiz solicitando sua aplicação, do que resulta extremamente importante a forma de redação da norma em questão"; ou (b) "a regra seja suficientemente específica para ser aplicada judicialmente, sem que sua execução esteja subordinada a um ato legislativo ou administrativo subsequente".40

Esta, no entanto, não é a diretriz condizente com o regime jurídico dos direitos fundamentais ${ }^{41}$ definido na Constituição brasileira. A autoaplicabilidade do tratado está, sim, delineada no art. $5^{\circ}, \$ 1^{\circ}$ da Constituição, e significa a desnecessidade de intermediação legislativa para o fim de garantir o exercício dos direitos humanos consagrados nos pactos internacionais, o que exige condutas omissivas e comissivas por parte da Administração Pública, do Legislativo e do Judiciário. Os tratados de direitos humanos, antes celebrados de modo a impor obrigações aos Estados perante os cidadãos ou estrangeiros, reconhecem por força da norma constitucional direitos diretamente exigíveis pelo indivíduo. ${ }^{42} \mathrm{O}$ reconhecimento progressivo da personalidade jurídica da

40 HENDERSON, Humberto. Los tratados internacionales de derechos humanos en el orden interno: la importancia del princípio pro homine. Revista IIDH, San José, v. 39, p. 71-99, 2004. p. 83-84.

41 A diferença entre direitos fundamentais e direitos humanos para grande parte da doutrina está na positivação. Ambos seriam uma mesma classe de direitos, cuja diferença estaria no "espaço institucional de positivação". Os direitos humanos são próprios do plano internacional. Os direitos fundamentais, do plano constitucional interno. (TORELLY, Marcelo. Governança transversal... Op. Cit., p. 96). Essa posição, aqui adotada, enfrenta críticas de quem sustenta ser a distinção um falso problema. Nesse sentido, disserta Alexandre Coutinho Pagliarini: "Má doutrina brasileira prega sobre 'diferença' entre Direitos Humanos e Direitos Fundamentais o seguinte: (i) os Direitos Humanos são provenientes da tradição do Direitos das Gentes; (ii) os Direitos Fundamentais são de matriz constitucional. Pois erram e mentem tais doutrinadores, e eles sabem disso. Erram e mentem pelo seguinte: a Constituição brasileira - e várias outras - têm em seus textos esta expressão; logo, ela não pode ser uma expressão de uso exclusivo do DIP justamente por ser da tradição constitucional o uso da expressão Direitos Humanos - a começar pela Déclaration francesa de 1789. Dizem os mesmos 'doutrinadores' que a expressão Direitos Fundamentais é de tradição nacionalista, comum das (e nas) Constituições; erram eles novamente, e a prova maior disso é que o mais importante documento normativo de Direitos Humanos que é usado pela Corte Europeia de Direitos Humanos (de Estrasburgo) se chama justamente Carta Europeia de Direitos Fundamentais, aprovada em Nice numa Convenção ocorrida em 2002". (PAGLIARINI, Alexandre Coutinho. Teoria geral e crítica do Direito Constitucional e Internacional dos Direitos Humanos. In: PAGLIARINI, Alexandre Coutinho; DIMOULIS, Dimitri (Coord.). Direito Constitucional e Internacional dos Direitos Humanos. Belo Horizonte: Fórum, 2012. p. 45).

42 “Os instrumentos do sistema interamericano são de aplicação direta (...). O denominado 'efeito direto' das regras convencionais, do sistema universal e do interamericano, é a característica que se lhes dotou". (SANTOFIMIO GAMBOA, Jaime Orlando. El concepto de convencionalidad... Op. Cit., p. 212). 
pessoa pelo Direito Internacional logo permitiu à doutrina defender a aplicabilidade imediata dos tratados e a invocação dos direitos neles consagrados pelos indivíduos. ${ }^{43}$

A aplicabilidade direta das normas dos tratados, apesar de um desafio constante, é o mecanismo privilegiado de efetivação dos direitos humanos previstos nas convenções internacionais. ${ }^{44}$ Os tratados internacionais de direitos humanos em vigor no ordenamento jurídico brasileiro são self-executing na linguagem internacionalista. A expressão significa que qualquer tipo de norma de direitos humanos "consagra um direito individual, passível de pronta aplicação ou execução pelos tribunais ou juízes nacionais", pois "não há, como a rigor nunca houve, qualquer impossibilidade lógica ou jurídica de que indivíduos, seres humanos, sejam beneficiários diretos de instrumentos internacionais". ${ }^{45}$ Entre esses direitos imediatamente aplicáveis estão inclusive aqueles classificados como direitos econômicos, sociais e culturais ${ }^{46}$, notadamente pela característica da indivisibilidade. ${ }^{47}$

A Constituição de 1988 impulsionou a ratificação de diversos tratados de direitos humanos por meio da regra que dá primazia aos direitos humanos nas relações internacionais, e na forma da sistemática acima explicada, esses tratados são aplicáveis imediatamente independentemente de mediação legal. ${ }^{48}$ Em outras palavras, o tratado não deixa de ser norma internacional quando incorporado. A promulgação pelo Presidente da República apenas declara o fim do processo de inserção do tratado, que passa a garantir direitos subjetivos a partir da publicação do ato executivo no diário oficial com o tratado anexo. ${ }^{49}$ Quer dizer, a publicação do decreto executivo é prática nacional que faz iniciar a vigência do tratado, porém o decreto não é efetivamente "positivador da norma pactícia internacional". Como a Constituição em diversos dispositivos invoca a existência na ordem jurídica interna de tratados (e não de decretos com texto

\footnotetext{
43 PEREIRA, André Gonçalves; QUADROS, Fausto de. Manual de Direito Internacional Público. 3. ed. Coimbra: Almedina, 1993. p. 392-393.

44 TRINDADE, Antônio Augusto Cançado. A humanização... Op. Cit., p. 125.

45 TRINDADE, Antônio Augusto Cançado. Tratado de Direito... Op. Cit., p. 539.

46 A multifuncionalidade dos direitos fundamentais afasta, quanto à negativa da aplicabilidade imediata, argumentos econômicos ou sobre a indeterminabilidade do conteúdo dos direitos sociais. A mesma lógica vale para os direitos humanos previstos em tratados, sejam eles direitos "civis e políticos" ou "direitos econômicos, culturais e sociais". Para a construção completa e exaustiva das razões pelas quais o regime dos direitos de liberdade e direitos sociais é o mesmo, cf. HACHEM, Daniel Wunder. Tutela administrativa efetiva dos direitos fundamentais sociais: por uma implementação espontânea, integral e igualitária. Curitiba, 2014. 604 p. Tese (Doutorado em Direito) - Universidade Federal do Paraná, Setor de Ciências Jurídicas, Programa de Pós-Graduação em Direito, Curitiba, 2014. p. 129-143.

47 TRINDADE, Antônio Augusto Cançado. Tratado de Direito... Op. Cit., p. 478.

48 LASCALA, Maria Carolina Florentino. A relativização da soberania em prol dos direitos humanos. Revista de Direito Público, Londrina, v. 6, n. 2, p. 87-102, ago./set. 2011. p. 94.

49 FRAGA, Mirtô. A obrigatoriedade do tratado... Op. Cit., p. 317.
} 
idêntico), o que vige e serve de parâmetro de controle é o tratado em si, e portanto é ele a norma aplicável. ${ }^{50}$

Por essas razões de ordem técnica, os tratados de direitos humanos vigoram com força normativa no ordenamento jurídico brasileiro ao lado de qualquer outra norma produzida pelo Poder Legislativo. Uma vez em vigor, o "tratado é norma jurídica e será encampado como tal no âmbito do direito interno do Estado pactuante. Produz efeitos, como norma jurídica, com a mesma força que também produzem as normas jurídicas domésticas (...)".51

Mas além dessas razões, outra de forte índole internacional confirma a vocação expansiva das normas vigentes no Direito brasileiro. No ano de 2009 foi promulgada e publicada em diário oficial a Convenção de Viena sobre Direito dos Tratados, uma das mais importantes normas sobre o tema e que regula os principais aspectos de vigência, interpretação e aplicação de tratados internacionais no mundo todo. ${ }^{52} \mathrm{~A}$ Convenção foi internalizada no Direito brasileiro pelo Decreto Executivo n. 7.030 de 14/12/2009 e agora há no ordenamento interno o reconhecimento expresso de princípios universais do costume internacional, tais como o livre-consentimento, a boa-fé e o pacta sunt servanda..$^{53}$

A Convenção de Viena sobre o Direito dos Tratados é fonte direta de Direito Internacional. ${ }^{54}$ Com mais força ainda, desde que o Brasil internalizou a Convenção de Viena em 2009, passou a reconhecer o princípio do pacta sunt servanda, segundo o qual se obriga a cumprir de boa-fé os tratados incorporados, vedada a utilização de razões de Direito interno para escusar-se da aplicação dos tratados aos quais aderiu (art. 27). ${ }^{55}$ É assente historicamente na doutrina internacional que o que torna obrigatório um tratado é o princípio do pacta sunt servanda consagrado ao longo dos séculos. ${ }^{56}$ Assim como nos contratos, ${ }^{57}$ o Estado que se obriga a um acordo deve cumpri-lo para fazer valer o Direito. ${ }^{58}$

50 PAGLIARINI, Alexandre Coutinho. Constituição e Direito Internacional: cedências possíveis no Brasil e no mundo globalizado. Rio de Janeiro: Forense, 2004. p. 155.

51 Idem, p. 129.

52 HILDEBRANDO, Accioly; SILVA, Geraldo E. do Nascimento e; CASELLA, Paulo Borba. Manual de Direito Internacional Público. 21. ed. São Paulo: Saraiva, 2014. p. 154.

53 Idem, p. 215.

54 RANGEL, Vicente Marotta. Direito e relações internacionais. 5. ed. São Paulo: Revista dos Tribunais, 1997.

55 (Convenção de Viena) Art. 27. Uma parte não pode invocar as disposições de seu direito interno para justificar o inadimplemento de um tratado. Esta regra não prejudica o artigo 46.

56 SANTOFIMIO GAMBOA, Jaime Orlando. El concepto de convencionalidad... Op. Cit., p. 291.

57 "(...) os princípios lex inter partem e pacta sunt servanda fazem certo que o contrato é a lei entre as partes e que estas, devidamente ajustadas, devem observar o que foi pactuado". (BACELLAR FILHO, Romeu Felipe. Reflexões... Op. Cit., p. 177).

58 MELLO, Celso D. de Albuquerque. Curso de Direito Internacional Público. 15. ed. v. I. Rio de Janeiro: Renovar, 2004. p. 221. 
Embora antes da recepção da Convenção de Viena em 2009 o Brasil já se vinculasse ao princípio, atualmente é totalmente seguro dizer que o país, a partir da publicação do Decreto Executivo n. 7.030 de 14/12/2009, detém regramento específico no sistema positivo que "orienta como se deve dar a relação entre direito interno e direito internacional pelas próximas gerações".59 O Brasil finalmente se adequou à tendência mundial de valorização do Direito Internacional, ${ }^{60}$ e a integração da Convenção de Viena em 2009 assegurou o caminho à internacionalização do sistema jurídico e reconhecimento de uma ordem jurídica una. ${ }^{61} \mathrm{O}$ país aceitou expressamente a norma de que não pode invocar razões de Direito interno para descumprir uma obrigação internacional. ${ }^{62}$

\section{HIERARQUIA SUPRACONSTITUCIONAL DOS TRATADOS DE DI- REITOS HUMANOS ADMITIDA PELA CONSTITUIÇÃO BRASILEI-} RA

A definição da hierarquia dos tratados de direitos humanos no ordenamento jurídico brasileiro centraliza as discussões doutrinárias e jurisprudenciais há tempos. Realmente, não passa despercebida a importância de definir em que patamar hierárquico se encontram as normas de direitos humanos previstas em tratados internacionais recepcionados pelo Direito brasileiro. Definir em que degrau da pirâmide normativa estão alocadas ditas normas importa para a aplicação do Direito objetivo e eleição

59 HILDEBRANDO, Accioly; SILVA, Geraldo E. do Nascimento e; CASELLA, Paulo Borba. Manual... Op. Cit., p. 236.

60 "Efetivamente, a tendência, até dos governos que ratificaram a Convenção de Viena sobre Direito dos Tratados, é a de começarem abrir as suas soberanas portas para o entendimento de que o DIP é superior e deve ser aplicado, implementando-se, assim, maior centralidade ao DIP, e fugindo-se, destarte, do primitivismo aqui denunciado cientificamente. Tal tendência é o que se depreende do preâmbulo da Convenção de Viena sobre - Direito dos Tratados, quando: 1) reconhece a importância cada vez maior dos tratados como fonte do direito internacional e como meio de desenvolver a cooperação pacífica entre as Nações, quaisquer que sejam os seus regimes constitucionais e sociais; 2) constata que os princípios do livre consentimento e da boa-fé e a regra pacta sunt servanda são universais; 3 ) proclama o respeito universal e efetivo dos direitos do homem e das liberdades fundamentais; 4) afirma que as regras do Direito Internacional Consuetudinário continuarão a reger as questões não reguladas na Convenção de Viena sobre o Direito dos Tratados". (PAGLIARINI, Alexandre Coutinho. Teoria geral e crítica... Op. Cit., p. 38)

61 "Doravante, há de se incorporar à prática judicial e administrativa o que já foi recebido pelo direito positivo, no sentido de que o direito é mais vasto do que o conjunto de normas que se edita, em casa, nos âmbitos federal, estadual e municipal". (HILDEBRANDO, Accioly; SILVA, Geraldo E. do Nascimento e; CASELLA, Paulo Borba. Manual... Op. Cit., p. 236).

62 Em matéria de direitos humanos, em alguns casos, declarações internacionais também são de aplicação obrigatória pelo Estado. A distinção classicamente aceita entre os métodos de codificação está entre a declaração internacional e as convenções ou tratados internacionais. Enquanto a declaração não teria força obrigatória, a convenção teria força jurídica vinculante depois de aceita pelos Estados. No entanto, para grande parte dos estudiosos de Direito Internacional dos Direitos Humanos algumas declarações, pela sua importância histórica e ética, seriam detentoras de força normativa, sendo o exemplo mais emblemático a Declaração Universal dos Direitos Humanos de 1948. Cf. nesse sentido, FRIEDRICH, Tatyana Scheila. As normas imperativas do Direito Internacional Público: Jus Cogens. Belo Horizonte: Fórum, 2004. 
da norma prevalente em situações concretas, inclusive naquelas em que há conflito insanável entre normas. É dizer, encontrar o status hierárquico das normas será de suma importância para que a Administração Pública, o Poder Legislativo e o Judiciário no exercício de suas competências apliquem corretamente o Direito e não contribuam para incoerências, ilegalidades ou inconstitucionalidades em prejuízo dos destinatários das normas legais.

Na Teoria do Direito, a Constituição é a principal norma com potencial para admitir fontes jurídicas diversas, atribuindo a elas os modos de interpretação e hierarquia. ${ }^{63} \mathrm{~A}$ Constituição é o instrumento normativo acumulador dos consensos e estabilizador das tensões sociais, ${ }^{64}$ e seria de todo precipitado dispensar sua importância ou relativizar seu poder de gerar segurança social e servir de parâmetro orientador de validade e recepção das normas jurídicas..$^{65}$

No Brasil, a Constituição não define categoricamente a hierarquia dos tratados internacionais. Há, contudo, dispositivos constitucionais que permitem inferir por meio de interpretação sistemática qual é o patamar hierárquico dos instrumentos internacio-

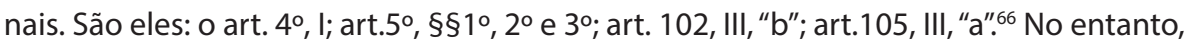
a leitura dessas normas constitucionais abarca uma plêiade de interpretações que confere aos tratados internacionais tantas hierarquias no ordenamento jurídico brasileiro quanto autores dispostos a descrevê-las.

Ao levar dez anos desde a promulgação da Constituição para reconhecer sua submissão à jurisdição da Corte IDH, o Brasil demorou a considerar problemática a interpretação do art. 5०, $\$ 2^{\circ}$, norma de abertura constitucional aos tratados de direitos

63 HESPANHA, Antonio Manuel. O caleidoscópio do Direito: o Direito e a justiça nos dias e no mundo de hoje. 2. ed. Coimbra: Almedina, 2009. p. 537.

64 Para além disso, as Constituições são hoje "documentos normativos do Estado e da sociedade. (...) A Constituição não apenas regula o exercício do poder, transformando a potestas em autorictas, mas também impõe coordenadas específicas para o Estado, apontando o vetor da sua ação. A Constituição opera força normativa, vinculando, positiva e negativamente, os poderes públicos. Os cidadãos têm, agora, acesso direito à normativa constitucional, inclusive para buscar proteção contra o arbítrio ou a omissão do legislador". (CLÈVE, Clèmerson Merlin. Para uma dogmática constitucional emancipatória. Belo Horizonte: Fórum, 2012. p. 38).

65 HESPANHA, Antonio Manuel. Pluralismo jurídico... Op. Cit., p. 250-252.

66 (Constituição Federal) Art. 4 A República Federativa do Brasil rege-se nas suas relações internacionais pelos seguintes princípios: II - prevalência dos direitos humanos.

Art. $5^{\circ}\left(\right.$...) $\S 1^{\circ}$ As normas definidoras dos direitos e garantias fundamentais têm aplicação imediata. $\S 2^{\circ}$ Os direitos e garantias expressos nesta Constituição não excluem outros decorrentes do regime e dos princípios por ela adotados, ou dos tratados internacionais em que a República Federativa do Brasil seja parte. $\S 3^{\circ}$ Os tratados e convenções internacionais sobre direitos humanos que forem aprovados, em cada Casa do Congresso Nacional, em dois turnos, por três quintos dos votos dos respectivos membros, serão equivalentes às emendas constitucionais.

Art. 102. Compete ao Supremo Tribunal Federal, precipuamente, a guarda da Constituição, cabendo-Ihe: III julgar, mediante recurso extraordinário, as causas decididas em única ou última instância, quando a decisão recorrida: b) declarar a inconstitucionalidade de tratado ou lei federal.

Art. 105. Compete ao Superior Tribunal de Justiça: III - julgar, em recurso especial, as causas decididas, em única ou última instância, pelos Tribunais Regionais Federais ou pelos tribunais dos Estados, do Distrito Federal e Territórios, quando a decisão recorrida: a) contrariar tratado ou lei federal, ou negar-lhes vigência. 
humanos. A temática, a rigor, só começou a ser discutida depois de um aprofundamento da influência de decisões internacionais, após a inserção de um grande número de tratados de direitos humanos na década de 90, e principalmente quando o Supremo Tribunal Federal foi provocado a decidir sobre a possibilidade da prisão civil por dívidas. $^{67}$

Se a Constituição é omissa ou dúbia no que tange à hierarquia dos tratados, tanto mais importante é o papel da jurisprudência nesse campo, a qual não pode ignorar a doutrina de maior relevo na atualidade. ${ }^{68} \mathrm{Na}$ linha do sobredito, existem inúmeras interpretações possíveis a respeito da hierarquia dos tratados internacionais de direitos humanos, e apesar de algumas se encontrarem em descompasso com o atual nível protetivo do Direito Internacional dos Direitos Humanos, todas são dignas de nota e respeito.

A seguir serão explicadas as principais correntes sobre a hierarquia dos tratados de direitos humanos, não havendo espaço para uma revisão de todas as nuances hermenêuticas do tema, as quais se aprofundaram a partir da edição da Emenda Constitucional n. 45/2004 (EC n. 45/04). A emenda, entre tantas inovações, inseriu o $\$ 3^{\circ}$ ao art. $5^{\circ}$ da Constituição com o suposto intuito de resolver a controvérsia instaurada a partir de 1988 relativa ao patamar hierárquico dos tratados de direitos humanos no Brasil. Contudo, a norma não resolveu definitivamente a questão, deixando aspectos em aberto, conforme se demonstrará a seguir.

Fundamentalmente são quatro as correntes interpretativas do art. $5^{\circ}, \S \S 1^{\circ}, 2^{\circ} \mathrm{e}$ $3^{\circ}$ da Constituição sobre a posição ocupada pelos tratados de direitos humanos no Direito brasileiro. Segundo cada qual, os tratados terão hierarquia: (4.1) legal, equiparada à posição das leis ordinárias; (4.2) supralegal, isto é, acima das leis e abaixo da Constituição; (4.3) constitucional, no mesmo patamar que as normas da Lei Fundamental; (4.4) supraconstitucional, com prevalência sobre qualquer norma interna, inclusive aquelas radicadas na Constituição.

Cada corrente explicada assume variações importantes, principalmente no ponto em que aceitam (ou não) a aplicação do critério de resolução de antinomia da prevalência da norma mais favorável ao ser humano. O que importa para os fins deste estudo, porém, é a demonstração dos principais argumentos de cada corrente e suas deficiências, o que tem como finalidade a verificação do patamar hierárquico que os tratados de direitos humanos assumem em comparação com outras espécies de normas jurídicas e de que modo eles as afetam.

67 GALINDO, George Rodrigo Bandeira. O $\S 3^{\circ}$ do art. $5^{\circ}$ da Constituição Federal: um retrocesso para a proteção internacional dos direitos humanos no Brasil. Revista do Instituto Brasileiro de Direitos Humanos, Fortaleza, v. 6, n. 6, p. 121-131, 2005. p. 122.

68 MELLO, Celso D. de Albuquerque. Curso... Op Cit., p. 131. 


\subsection{Hierarquia legal dos tratados internacionais de direitos huma- nos}

Na ordem proposta, em primeiro lugar aparece a corrente defensora do patamar hierárquico legal das normas definidoras de direitos humanos previstas em tratados internacionais. Essa posição, diga-se desde já, é absolutamente minoritária, embora tenha prevalecido no Supremo Tribunal Federal entre a década de 1970 até o ano de 2008, radicada no precedente do Recurso Extraordinário n. 80.004-SE. ${ }^{69}$

O principal argumento dessa corrente, hoje ultrapassada, é a afirmação de que a soberania estatal estaria em perigo acaso a recepção de tratados com hierarquia privilegiada fosse aceita mediante procedimento menos rigoroso do que o da aprovação de emendas constitucionais. Para essa corrente, o significado do art. $5^{\circ}, \S 2^{\circ}$ da Constituição seria limitado, e os tratados só serviriam para reforçar os direitos fundamentais previstos no próprio art. $5^{\circ}$ ou assimilar princípios que com eles não conflitassem. Todo tratado contrário a um direito previsto na Constituição seria, portanto, inconstitucional, conclusão que levaria inclusive à possibilidade da previsão prisão civil do depositário infiel a despeito das vedações no do art. 11 do Pacto dos Direitos Civis e Políticos e do art. 7.7 do Pacto de São José da Costa Rica, ambos em vigor no Brasil. ${ }^{70}$

Entre os autores dessa corrente, alegadamente em defesa da supremacia da Constituição, Manoel Gonçalves Ferreira Filho advoga pela hierarquia legal de todos os tratados internacionais. Conquanto se curve à atual posição do Supremo Tribunal Federal, mais abaixo explicada, o autor afirma que, no seu entendimento doutrinário, "as normas do Pacto de São José da Costa Rica, a que adere o Brasil, não prevaleceriam sobre o direito constitucional positivo brasileiro. Teriam apenas a força de legislação ordinária".71

Manoel Gonçalves Ferreira Filho defende que o art. $5^{\circ}$, $\$ 2^{\circ}$ da Constituição serve somente para explicitar o caráter declarativo dos direitos previstos em tratados (direitos esses que estariam de qualquer forma previstos explícita ou implicitamente já na

69 O recurso não discutia a incidência de normas de direitos humanos, mas de tratado de Direito Comercial, mais especificamente a Convenção de Genebra - Lei Uniforme sobre Letras de Câmbio e Notas Promissórias. Naquela oportunidade, o tratado foi equiparado à lei ordinária e o conflito entre as normas foi resolvido pelo critério temporal (lex posteriori). A jurisprudência foi repetida mais tarde em matéria que envolvia a prisão civil do depositário infiel e a Convenção Americana da Direitos Humanos, tanto no Habeas Corpus n. 72.131-RJ quanto em outros julgados. Cf. BRASIL. Supremo Tribunal Federal. Recurso Extraordinário n. 80.004-SE. Tribunal Pleno. Relator Min. Xavier de Albuquerque. Julgamento em 01/06/1977. Publicado em 29/12/1977; BRASIL. Supremo Tribunal Federal. Habeas Corpus n. 72.131-RJ. Tribunal Pleno. Relator para acórdão Min. Moreira Alves. Julgamento em 23/11/1995. Publicado em 28/11/1995.

70 RODRIGUES, Maurício Andreiuolo. Os tratados internacionais de proteção dos direitos humanos e a Constituição. In: TORRES, Ricardo Lobo (Org.). Teoria dos Direitos Fundamentais. 2. ed. Rio de Janeiro: Renovar, 2001. p. 157-195.

71 FERREIRA FILHO, Manoel Gonçalves. Direitos humanos fundamentais. 14. ed. São Paulo: Saraiva, 2012. p. 125. 
Constituição). O regime, em todo caso, seria diverso para os direitos convencionais, que seguiriam os preceitos aplicáveis à legislação ordinária, sendo permitido em relação a eles, portanto, até mesmo a declaração de inconstitucionalidade ou revogação por lei posterior. Apenas aqueles tratados aprovados pelo procedimento do art. $5^{\circ}, \S 3^{\circ} \mathrm{da}$ Constituição (similar ao de aprovação de emendas constitucionais) é que possuiriam, segundo o mesmo autor, hierarquia constitucional e seguiriam, desta forma, o mesmo regime dos direitos fundamentais. ${ }^{72}$

Igualmente em nome da soberania estatal, Alexandre de Moraes acompanha a corrente minoritária defensora da hierarquia infraconstitucional dos tratados de direitos humanos. Também para ele, apenas os tratados incorporados na forma do art. 5०, $\S 3^{\circ}$ teriam hierarquia constitucional, resguardada a possibilidade de controle de sua constitucionalidade em virtude de serem equivalente a emendas. ${ }^{73}$

Essa corrente apoia-se ainda em outros dispositivos constitucionais regulamentadores dos recursos cabíveis no Supremo Tribunal Federal e Superior Tribunal de Justiça para discussão sobre constitucionalidade de tratado (art. 102, III, "b") e negativa de vigência de tratado (art. 105, III, “a”). A Constituição, ao prever a possibilidade de recurso ao Supremo Tribunal Federal contra decisão que declarou a inconstitucionalidade de tratado, bem como a possibilidade de recurso dirigido ao Superior Tribunal de Justiça contra decisão que contrariou ou negou vigência de tratado (tal como permite nos casos de negativa de vigência ou contrariedade à lei federal), estaria - segundo esses autores - admitindo implicitamente a hierarquia legal de todos os tratados. A norma do art.102, III, "b" da Constituição reconheceria a possibilidade de declaração de inconstitucionalidade de tratados, o que, se acontecesse, deveria levar à denúncia do tratado segundo as regras de Direito Internacional. ${ }^{74} \mathrm{O}$ mesmo no caso em que uma lei posterior contraria e revoga as normas de um tratado (ou paralisa seus efeitos). Nesses casos, até que se completasse o processo de denúncia, o Brasil estaria sujeito a responsabilização internacional por descumprimento do tratado. Caberia como solução, por exemplo, o Judiciário modular os efeitos da declaração de inconstitucionalidade de modo a preservar o país de sofrer responsabilização internacional.

Essa corrente, no entanto, deixa de considerar que no tocante aos tratados internacionais de direitos humanos o entendimento deve ser outro. $\mathrm{O}$ argumento que se funda na interpretação do art. 102, III, "b" e do art. 105, III, "a" da Constituição, apesar de lógico, desconsidera o sentido da cláusula de abertura do art. $5^{\circ}, \S 2^{\circ} \mathrm{e}$ a norma que estabelece a prevalência dos direitos humanos nas relações internacionais, inserida no art. 4, II da Constituição. A leitura sistemática da Constituição retira a força da tese da

\footnotetext{
72 Idem, p. 126.

73 MORAES, Alexandre de. Direitos humanos fundamentais: teoria geral, comentários aos arts. $1^{\circ}$ a $5^{\circ}$ da Constituição da República Federativa do Brasil, doutrina e jurisprudência. 9. ed. São Paulo: Atlas, 2011. p. 360.

74 MELLO, Celso D. de Albuquerque. Curso... Op. Cit., p. 132.
} 
hierarquia legal, sustentada apenas por quem ignora os avanços do Direito Internacional dos Direitos Humanos e o processo de relativização de soberania por que passam todos os ordenamentos jurídicos do mundo. Por isso, atualmente poucos sustentam o patamar hierárquico legal dos tratados de direitos humanos.

\subsection{Hierarquia supralegal dos tratados internacionais de direitos hu- manos: posição atual do Supremo Tribunal Federal}

Em função da jurisprudência sumulada do Supremo Tribunal Federal, os tratados internacionais de direitos humanos ostentam hoje, no mínimo, uma posição mais vantajosa do que a lei produzida pelo Congresso brasileiro. Segundo a posição atual do Supremo Tribunal Federal, uma lei só será válida no ordenamento brasileiro quando passar pelo teste de dupla compatibilidade vertical com a Constituição e com as normas de Direito Internacional de Direitos Humanos. ${ }^{75}$

Esse posicionamento consolidado na Súmula Vinculante n. 25, proibitiva da prisão civil por dívidas ${ }^{76}$, originou-se no julgamento do Recurso Extraordinário n. 466.343SP pelo Supremo Tribunal Federal, após longo percurso de afirmação do Direito Internacional dos Direitos Humanos no Brasil. No julgamento ocorrido em 03/12/2008 - mesma data em que foram julgados o Recurso Extraordinário n. 349.703/RS e os Habeas Corpus n. 92.566-SP e n. 87.585-TO - o Judiciário brasileiro reconheceu a impossibilidade de manutenção do entendimento retrógrado e fechado que pretendia a hierarquia legal dos tratados de direitos humanos incorporados.

A controvérsia resumia-se à interpretação do art. $5^{\circ}, \mathrm{LXVII}$ e dos $\S \S 1^{\circ}, 2^{\circ}$ e $3^{\circ}$ da Constituição à luz do art. 7.7 da Convenção Americana sobre Direitos Humanos. A primeira é norma constitucional autorizadora da prisão civil do depositário infiel. $\mathrm{O}$ art. $5^{\circ}$ e $\S \S 2^{\circ}$ e $3^{\circ}$, como se viu, são normas de abertura do sistema à ordem jurídica internacional e de recepção de tratados de direitos humanos. Por fim, a norma do art. 7.7. do Pacto de São José da Costa Rica é garantia de que ninguém terá a liberdade restringida

75 MAZZUOLI, Valerio; GOMES, Luiz Flávio. Tratados internacionais... Op. Cit., p. 19.

76 Há quem repute inconstitucional e contrária aos tratados internacionais de direitos humanos a Súmula Vinculante $n^{\circ} 25$, porque ao ampliar as hipóteses em que proibida a prisão civil para as prisões decorrentes de infidelidade em depósitos judiciais, nos quais vigora uma relação de Direito Processual, a súmula teria ido além do que proíbe o Pacto Internacional dos Direitos Civis e Políticos no art. 11, o Pacto de São José da Costa Rica no art. $7^{\circ}$ e a própria Constituição no art. $5^{\circ}$, LXVII. Ela teria extrapolado a normativa nacional e internacional quando estendeu a proibição a "todas as modalidades de depósito". Para os defensores dessa posição, embora seja proibida a prisão civil por dívidas, e consequentemente a prisão do depositário infiel partícipe de relações privadas, não estaria proibida a prisão civil do depositário infiel partícipe de relação jurídica processual pública (o depositário judicial). Essa posição estaria em consonância com o direito fundamental à tutela jurisdicional efetiva derivado do art. 50, XXXV da Constituição. Para maiores detalhes sobre esse posicionamento, cf. OLIVEIRA, Douglas Henrique de; TACLA, Silvia Regina. Reflexões acerca da possibilidade da Prisão Civil do Depositário Judicial Infiel e tutela jurisdicional efetiva. Revista do Direito Público, Londrina, v.8, n. 1, p.189-214, jan./abr. 2013. 
por dívidas, salvo uma exceção: “Ninguém deve ser detido por dívidas. Este princípio não limita os mandados de autoridade judiciária competente expedidos em virtude de inadimplemento de obrigação alimentar".

Por maioria, ${ }^{77}$ superando a jurisprudência estabelecida na década de 1970, o Supremo Tribunal Federal adotou o entendimento proposto pelo Min. Gilmar Mendes, atribuindo hierarquia supralegal aos tratados de direitos humanos. Os votos são díspares, e alguns dos Ministros nem mesmo entenderam necessário invocar o art. $5^{\circ}, \S \S 1^{\circ} \mathrm{a}$ $3^{\circ}$ da Constituição para resolver o impasse trazido à Corte. Entretanto, a relevância do julgado está nos argumentos acatados pela maioria dos julgadores e que serviram à construção do entendimento em vigência sobre a hierarquia dos tratados.

O posicionamento prevalente no Supremo Tribunal Federal baseia-se, entre outros fundamentos, na EC n. 45/2004. Diante do art. 5, $\$ 3^{\circ}$ adicionado pelo Poder Reformador por meio da referida emenda em 2004, modificou-se a jurisprudência da Suprema Corte a partir de 2008, ano em que o Tribunal passou a adotar expressamente a teoria do duplo estatuto dos tratados de direitos humanos. Os tratados incorporados pelo procedimento do art. $5^{\circ}, \S 3^{\circ}$, segundo o Supremo Tribunal Federal, têm status constitucional, enquanto os tratados de direitos humanos incorporados na forma tradicional ou antes da referida emenda têm hierarquia supralegal. ${ }^{78}$ Teoricamente, dúvidas sobre a hierarquia dos tratados teriam se dissipado e todos os tratados de direitos humanos anteriormente incorporados só poderiam ostentar status equivalente ao de emendas constitucionais caso passassem pelo rigoroso rito previsto no art. $5^{\circ}, \S 3^{\circ} \mathrm{da}$ Constituição, ${ }^{79}$ não obstante outras interpretações tenham sido propostas. ${ }^{80}$

\footnotetext{
77 Votaram pela tese da supralegalidade dos tratados os Ministros Gilmar Mendes, Menezes Direito, Ricardo Lewandowski, Cármen Lúcia e Carlos Ayres Britto. A seu turno, votaram pela hierarquia constitucional dos tratados os Ministros: Celso de Mello, Cezar Peluso, Eros Grau e Ellen Gracie. Os Ministros Joaquim Barbosa e Marco Aurélio não entenderam necessário adentrar na explicação da hierarquia dos tratados para resolver o caso.

78 RAMOS, André de Carvalho. Curso... Op. Cit., p. 396-397.

79 MENDES, Gilmar Ferreira. A supralegalidade dos tratados internacionais de direitos humanos e a prisão civil do depositário infiel no Brasil. In: BOGDANDY, Armin Von; PIOVESAN, Flávia; ANTONIAZZI, Mariela Morales (Coord.). Direitos humanos, democracia e integração jurídica: avançando no diálogo constitucional e regional. Rio de Janeiro: Lumen Juris, 2011. p. 227.

80 Paulo Ricardo Schier propôs o reconhecimento da hierarquia constitucional dos tratados de direitos humanos recepcionados antes da Emenda $n^{\circ} 45 / 2004$. A teoria do tempus regit actum levaria ao entendimento de que os tratados anteriores à emenda automaticamente assumiriam o status de emenda constitucional, a exemplo das leis ordinárias anteriores à Constituição de 1988 recepcionadas como leis complementares, como o Código Tributário Nacional. A tese passava pelo pressuposto de que todos os tratados posteriores à emenda estariam sujeitos obrigatoriamente ao rito do $\S 3^{\circ}$ do art. $5^{\circ}$ da Constituição. (SCHIER, Paulo Ricardo. Hierarquia Constitucional dos Tratados Internacionais de Direitos Humanos e EC 45 - tese em favor da incidência do tempus regit actum. In: CONGRESSO NACIONAL DO CONPEDI, 14., 2006, Florianópolis. Anais... Florianópolis: Fundação Boiteux, 2006. p. 161. Disponível em: <www.conpedi.org/manaus/arquivos/Anais/Paulo\%20Ricardo\%20 Schier.pdf $>$.)
} 
A mesma EC n. 45/2004 reconheceu a importância distintiva dos direitos humanos por meio de outras normas que se incorporaram à Constituição. ${ }^{81}$ Portanto, tornara-se anacrônica desde a emenda a tese da hierarquia legal desses tratados, outro motivo pelo cabia ao Supremo Tribunal Federal mudar seu posicionamento, e ao menos adotar a tese da supralegalidade. ${ }^{82}$ Apenas os tratados internacionais comuns teriam mantido a hierarquia legal. ${ }^{83}$

A solução técnica adotada na ocasião do julgamento do Recurso Extraordinário n. 466.343-SP foi, ao invés de declarar revogado o preceito constitucional autorizador da prisão civil do depositário infiel, declarar a "eficácia paralisante" das disposições infraconstitucionais regentes da matéria (art. 1.287 do Código Civil de 1916, art. 652 do Código Civil de 2002 e art. $1^{\circ}$ do Decreto-lei n. 911/1969). Desde a consolidação daquele posicionamento, a Suprema Corte entende que o art. 5०, LXVII da Lei Fundamental não pode ser aplicado porque se encontra "sem base legal"84 para permitir a sua aplicabilidade, diante da força normativa dos tratados de direitos humanos vigentes no Brasil que bloqueiam os efeitos das normas legais que regulamentam o dispositivo constitucional. Assim evitou-se colocar a Constituição abaixo do tratado.

A decisão majoritária do Supremo Tribunal Federal (que, aliás, não levou em consideração o art. 27 da Convenção de Viena, incorporada no ano seguinte no Brasil) merece ser criticada por ignorar a cláusula de abertura material do catálogo de direitos fundamentais, prevista no art. $5^{\circ}, \S 2^{\circ}$ da Constituição em sua redação originária. ${ }^{85}$ Principalmente, a tese da supralegalidade dos tratados não incorporados pelo procedimento do art. $5^{\circ}, \S 3^{\circ}$ da Constituição peca por atribuir regimes jurídicos diferentes a normas internacionais de mesma categoria e com o mesmo objetivo de proteção da pessoa humana. ${ }^{86} \mathrm{~A}$ tese da hierarquia supralegal também é problemática porque na realidade não existe efeito paralisante para o critério hierárquico de resolução de antinomias.

\footnotetext{
81 Por exemplo, a norma que reconhece a competência do Tribunal Penal Internacional, e a norma de deslocamento de competência ao Superior Tribunal de Justiça de casos de graves violações aos direitos humanos.

83 André de Ramos Carvalho indica que a interpretação do art. 27 da Convenção de Viena de 1969, incorporada em 2009, pode levar à alteração da jurisprudência do Supremo Tribunal Federal sobre a hierarquia dos tratados comuns, pois não é permitido ao Estado invocar razões de Direito interno para afastar um tratado (RAMOS, André de Carvalho. Curso... Op. Cit., p. 386). Embora alguns tenham indicado que a mudança iniciou no julgamento do Recurso Extraordinário n. 636.331-RJ e do Agravo em Recurso Extraordinário n. 766.618-SP, em 25.05.2016, no qual o Supremo Tribunal Federal decidiu a prevalência da Convenção Varsóvia e de Montreal em detrimento do Código de Defesa do Consumidor, parece que a decisão dos Ministros seguiu a lógica da princípio da supremacia constitucional neste caso. Os votos adotaram a conclusão final fundamentando a prevalência da norma internacional no art. 178 da Constituição, e não na Convenção de Viena.

84 MENDES, Gilmar Ferreira. A supralegalidade dos tratados... Op. Cit., p. 235.

85 MALISKA, Marcos Augusto. Constituição e cooperação normativa no plano internacional: reflexões sobre o voto do Ministro Gilmar Mendes no Recurso Extraordinário n. 466.343-1. Espaço Jurídico, Joaçaba, v. 9, n. 2, p. 113-124, jul./dez. 2008. p. 115.

86 GOMES, Luiz Flávio; MAZZUOLI, Valerio de Oliveira. Direito Supraconstitucional... Op. Cit., p. 89.
} 
Segundo esse critério, ou a regra é compatível ou incompatível com a de maior hierarquia, e nesse último caso deve ser declarada inválida. Dentro da compreensão exarada, salvo se a cláusula constitucional é aberta a ponto de requerer uma regulamentação detalhada, por coerência o tratado deveria ser constitucional ou inconstitucional, sem admitir uma terceira via. ${ }^{87}$ Não é essa a posição do Supremo Tribunal Federal, que encontrou um mecanismo inventivo de interpretação constitucional à luz de um tratado internacional (a eficácia paralisante).$^{88}$

Há quem proponha soluções interessantes para as incoerências geradas pela decisão do Supremo Tribunal Federal, como por exemplo a que admite em nível constitucional apenas a Convenção Americana sobre Direitos Humanos e o Tratado de Roma do Tribunal Penal Internacional. ${ }^{89}$ Essas posições, entretanto, são isoladas em comparação com o entendimento jurisprudencial orientado pela Súmula Vinculante n. 25. Isto é, hoje os tribunais brasileiros, por força da sistemática de vinculação existente, entendem que os tratados de direitos humanos se situam em patamar hierárquico supralegal, salvo se incorporados na forma do art. 5०, $\S 3^{\circ}$ da Constituição, como foi por

87 MALISKA, Marcos Augusto. Constituição e cooperação... Op. Cit., p. 119.

88 Basta cogitar situações em que o dispositivo constitucional não necessite de regulamentação legal. Nestes casos, "o entendimento do efeito paralisante ou impeditivo da lei disponibiliza a interpretação do conteúdo da Constituição ao disposto nos tratados, criando a figura da interpretação da Constituição conforme os Tratados". Veja-se que o entendimento é problemático caso mantida a orientação da natureza supralegal dos tratados de direitos humanos, pois a visão de que uma norma inferior condiciona o sentido de uma norma superior é contrária ao edifício kelseniano. Por isso é que, para Marcos Maliksa, o voto condutor do Min. Gilmar Mendes a pretexto de proteger o princípio da supremacia da Constituição acaba fazendo o contrário. (Idem, p. 118).

89 Caíque Tomaz Leite Silva e Carlos Eduardo Sindona de Oliveira defendem a obrigatoriedade de incorporação dos tratados de direitos na forma do art. $5^{\circ}, \S 3^{\circ}$. Para todos os tratados que não sejam equivalentes $a$ emendas, a hierarquia infraconstitucional teria justificativa numa fundamentação denominada hermenêutica. O argumento parte da EC n. 45/04 e do $§ 4^{\circ}$ do art. $5^{\circ}$ por ela incluído na Constituição. O dispositivo remete à submissão integral do Brasil ao Tribunal Penal Internacional. No entanto, o Brasil já assumira essa posição no ano de 2002, oportunidade em que o Decreto Executivo n 4.388 determinou o cumprimento do Estatuto de Roma. Assim, para os autores houve a manifestação indireta do Poder Constituinte derivado no sentido de constitucionalizar situação já incorporada no ordenamento jurídico pátrio. A EC teria constitucionalizado indiretamente um tratado de direitos humanos por meio do $\$ 4^{\circ}$ do art. $5^{\circ}$. Em relação a outros tratados, a emenda foi omissa e deixou aberta a constitucionalização pela via do art. $5^{\circ}, \S 3^{\circ}$. Esse argumento parte do pressuposto de que se a emenda reforçou a incorporação do Estatuto de Roma já em vigência no Brasil, estaria implícito no ordenamento jurídico o status infraconstitucional de todo tratado anterior à EC n. 45/04 não reforçado. Ao passo que o Estatuto de Roma seria uma norma constitucional, outros tratados não o seriam a não ser se incorporados na forma do art. 5०, $\$ 3^{\circ}$ da Constituição. E apesar do status infraconstitucional das Convenções anteriores à EC n. 45/04, em relação à Convenção Americana sobre Direitos Humanos seria impossível a denúncia. A posição do Supremo Tribunal Federal a respeito do efeito paralisante da Convenção sobre as disposições de Direito interno teria constitucionalizado o preceito que próibe a prisão civil por dívidas e o Pacto de São José da Costa Rica como um todo. Esse tratado de direitos humanos, portanto, teria hierarquia constitucional porque o Supremo Tribunal Federal quando editou a Súmula Vinculante n. 25 o tornou norma materialmente constitucional. (cf. SILVA, Caíque Tomaz Leite; OLIVEIRA, Carlos Eduardo Sindona de. O décimo aniversário da emenda 45 e a posição hierárquica dos tratados de direitos humanos. Revista do Direito Público, Londrina, v.11, n. 1, p. 137-162, jan./abr. 2016. p. 150-155). 
exemplo a Convenção sobre os Direitos das Pessoas com Deficiência e seu Protocolo Facultativo (Decreto n. 6.949/2009). ${ }^{90}$

Em função especialmente da apertada votação registrada nos precedentes que firmaram a tese da supralegalidade, ao contrário do que se pode supor, as discussões estão longe de se esgotar, o que torna o tema relevante e atual. ${ }^{91} \mathrm{~A}$ crescente invocação das normas de Direito Internacional de Direitos Humanos no cotidiano forense e a prevalência do entendimento doutrinário sobre a hierarquia constitucional dos tratados de direitos humanos incorporados ou não na forma do art. $5^{\circ}$, $\$ 3^{\circ}$ da Constituição indica mudanças de rumo no futuro próximo. ${ }^{92}$

\subsection{Hierarquia constitucional dos tratados internacionais de direitos humanos}

A corrente defensora da hierarquia constitucional dos tratados é a que conta com maior adesão doutrinária. Ela parte da leitura do art. $5^{\circ}, \S 2^{\circ}$ da Constituição, norma originária e, portanto, anterior às alterações da EC n. 45/2004. Para essa terceira corrente, todos os tratados de direitos humanos incorporados no Direito brasileiro teriam hierarquia constitucional por força do $\$ 2^{\circ}$ do art. $5^{\circ}$, que ao estabelecer que os direitos fundamentais constitucionais "não excluem" direitos previstos nas normas internacionais "está a autorizar que esses direitos e garantias internacionais constantes dos tratados internacionais de direitos humanos ratificados pelo Brasil 'se incluem' no nosso ordenamento jurídico interno, passando a ser considerados como se escritos na Constituição estivessem".93

A norma de abertura do art. $5^{\circ}, \S 2^{\circ}$ da Constituição incorpora os tratados internacionais de direitos humanos no texto da Lei Fundamental, transformando os direitos

\footnotetext{
90 Registre-se que, não obstante opiniões divergentes, a aprovação pelo rito do $\S 3^{\circ}$ do art. $5^{\circ}$ é facultativa. Tanto é assim que houve desde 2004 a aprovação de tratados de direitos humanos pelo rito de maioria simples, como por exemplo o Protocolo de Assunção sobre Compromisso com a Promoção e a Proteção dos Direitos Humanos do Mercosul (Decreto Legislativo n. 592/2009). Cabe ao Presidente da República solicitar a aprovação pelo quórum privilegiado de 3/5, ou então ao Congresso Nacional iniciar a aprovação do tratado nesses termos. A palavra final sobre o rito a ser adotado, no entanto, é sempre do Congresso, por força do art. 49, I da Constituição. (RAMOS, André de Carvalho. Curso... Op. Cit., p. 398-399).

91 MELO, Juliane Andréa de Mendes Hey; BONATO, Ariadne da Silveira. Cláusula de abertura dos direitos fundamentais e status hierárquico dos tratados internacionais de direitos humanos. Revista Direitos Humanos e Democracia, ljuí, a. 5, n. 9, p. 274-305, jan./jun. 2017. p. 303.

92 Exemplo das rupturas vivenciadas no Brasil acerca do tema é, mais uma vez, o recente episódio no Processo de Registro de Candidatura n 0600903-50.2018.6.00.0000-TSE. No caso já citado neste trabalho, Luiz Inácio Lula da Silva buscava candidatar-se à presidência apesar da suspensão de seus direitos políticos. No voto que iniciou o julgamento, do Min. Fachin, foi emblemática a defesa do caráter obrigatório de recomendação da Comitê de Direitos Humanos da ONU, o que contribuiu para movimentar no cenário jurídico também a rediscussão da hierarquia de normas jurídicas e decisões internacionais em matéria de direitos humanos.
}

93 GOMES, Luiz Flávio; MAZZUOLI, Valerio de Oliveira. Direito Supraconstitucional... Op. Cit., p. 103. 
previstos nas convenções em normas materialmente constitucionais. ${ }^{94} \mathrm{Em}$ favor dessa posição, estão argumentos como: (i) a abertura à ordem internacional como fator legitimador do Direito interno; (ii) a natureza constitucional material dos direitos fundamentais; (iii) o princípio da máxima efetividade da Constituição, cuja orientação é conferir às normas constitucionais a interpretação que melhor contribua para sua efetividade; (iv) a natureza especial dos tratados de direitos humanos, os quais objetivam a proteção da pessoa humana prioritariamente às razões de Estado; e (v) a interpretação teleológica e sistemática da Constituição, que tem na dignidade da pessoa humano seu eixo de sustentação. ${ }^{95}$

Antônio Augusto Cançado Trindade, que no cargo de Consultor Jurídico do Itamaraty sugeriu a redação do art. $5^{\circ}, \S 2^{\circ}$ da Constituição em sua versão original, é árduo defensor da hierarquia diferenciada dos tratados de direitos humanos em relação aos demais tratados. Em respeito ao art. $5^{\circ}, \S \S 1^{\circ}$ e $2^{\circ}$, os tratados de direitos humanos, segundo o autor, passam a "integrar o elenco dos direitos constitucionalmente consagrados direta e imediatamente exigíveis no plano do ordenamento jurídico interno". ${ }^{96}$

A dificuldade, no entanto, está em interpretar a hierarquia constitucional dos tratados em face da norma do art. 5०, §3 da Constituição, de consagração do rito mais rígido para recepção de tratados equivalentes a emendas constitucionais. Diante da emergência dessa norma, há até mesmo quem considere um retrocesso a inserção do $\S 3^{\circ}$ no art. $5^{\circ} .{ }^{97}$ Outros defendem pura e simplesmente a inconstitucionalidade da EC n. 45/2004, como Alexandre Coutinho Pagliarini, para quem o $\$ 3^{\circ}$ inserido seria inconstitucional "por violação explícita ao preexistente art. 60, §4, que, em português claro, prescreve que não deve ser objeto de deliberação proposta de emenda tendente a abolir (ou a diminuir o grau de abrangência) dos Direitos Fundamentais".98

94 Essa é a posição compartilhada, entre outros autores de igual importância, por: PIOVESAN, Flávia. Direitos humanos e o Direito... Op. Cit., p. 118; RAMOS, André de Carvalho. Curso... Op. Cit., p. 401; PAGLIARINI, Alexandre Coutinho. Teoria geral e crítica... Op. Cit.; HACHEM, Daniel Wunder. Tutela administrativa efetiva dos direitos fundamentais sociais... Op. Cit., p. 339; GALINDO, George Rodrigo Bandeira. O $\S 3^{\circ}$ do art. $5^{\circ}$ da Constituição Federal... Op. Cit., p. 127; MAZZUOLI, Valerio de Oliveira. Curso... Op. Cit., p. 900; MOREIRA, Thiago Oliveira. A aplicação dos tratados... Op. Cit., p. 168; SARLET, Ingo Wolfgang. Considerações a respeito das relações entre a Constituição Federal de 1988 e os tratados internacionais de direitos humanos. Espaço jurídico, Joaçaba, v. 12, n.2, p. 325-344, jul./dez. 2011. p. 342-343; TRINDADE, Antônio Augusto Cançado. Tratado de Direito... Op. Cit., p. 513; LAFER, Celso. A Internacionalização dos Direitos Humanos: constituição, racismo e relações internacionais. Barueri: Manole, 2005. p. 16-17; FACHIN, Luiz Edson. Notas para um ensaio sobre a posição jurídica dos tratados internacionais de direitos humanos no Brasil após a reforma constitucional. In: PRONER, Carol; CORREAS, Oscar (Coord.). Teoria crítica dos direitos humanos: in memoriam Joaquín Herrera Flores. Belo Horizonte: Fórum, 2011. p. 153-163; GOMES, Eduardo Biacchi. Controle de convencionalidade nos processos de integração - democracia e MERCOSUL (a construção de uma tese). A\&C - Revista de Direito Administrativo \& Constitucional, Belo Horizonte, a. 13, n. 52, p. 231-245, abr./jun. 2013. p. 235.

95 PIOVESAN, Flávia. Direitos humanos e o Direito... Op. Cit., p. 120-134.

96 TRINDADE, Antônio Augusto Cançado. Tratado de Direito... Op. Cit., p. 513.

97 GALINDO, George Rodrigo Bandeira. O $\$ 3^{\circ}$ do art. $5^{\circ}$ da Constituição Federal... Op. Cit., p. 127.

98 PAGLIARINI, Alexandre Coutinho. Teoria geral e crítica... Op. Cit., p. 42. 
Entretanto, não é preciso recorrer aos extremos a ponto de sustentar a inconstitucionalidade da EC n. 45/2004 neste ponto, porque uma interpretação conforme a Constituição autoriza a preservação da norma segundo uma leitura constitucionalmente adequada. ${ }^{99} \mathrm{~A}$ inclusão do $\$ 3^{\circ}$ no art. $5^{\circ}$ não é inconstitucional, pois não afetou o núcleo essencial da norma do $\$ 2^{\circ}$ do mesmo artigo. Existem interpretações que tornam possível a compatibilização dos dispositivos e essa é a diretriz a ser seguida. Além disso, é difícil sustentar a inconstitucionalidade de emenda contra uma das interpretações sobre o status dos tratados de direitos humanos (ainda que a majoritária), de sorte que a tese da inconstitucionalidade da EC n. 45/2004 não passa por uma análise mais cuidadosa. ${ }^{100}$

É preciso, portanto, interpretar o art. $5^{\circ}, \S 3^{\circ}$ sistematicamente na Constituição, principalmente em conjunto com o $\$ 2^{\circ}$, para compreender seu sentido. Uma posição possível é aquela que defende, de um lado, a constitucionalidade material dos tratados recepcionados anteriormente à EC n. 45/2004 (ou que, posteriormente a ela, foram aprovados por maioria simples no Congresso), e, de outro lado, a constitucionalidade material e formal dos tratados equivalentes a emendas constitucionais aprovados com quórum de $3 / 5$ em dois turnos em cada casa do Congresso Nacional.

A norma do art. $5^{\circ}, \S 3^{\circ}$ não descaracterizaria a natureza materialmente constitucional dos tratados. Assim, a regra deveria ser lida em conjunto com o $§ 2^{\circ}$ do mesmo artigo, e "está tão somente a reforçar tal natureza, ao adicionar um lastro formalmente constitucional aos tratados ratificados, propiciando a 'constitucionalização formal' dos tratados de direitos humanos no âmbito jurídico interno". ${ }^{101}$ A lógica interpretativa das normas constitucionais e normas internacionais de direitos humanos, o art. $5^{\circ}, \S 2^{\circ} \mathrm{da}$ Constituição e a teoria da recepção adotada no Brasil ${ }^{102}$ reforçariam o argumento de que o $\$ 3^{\circ}$ adicionado ao art. $5^{\circ}$ é meramente uma regra que atribui o status de norma constitucional formal aos tratados incorporados posteriormente à mencionada emenda. ${ }^{103}$ As consequências de recepcionar um tratado com status equivalente ao de emendas seriam: (i) reformar a Constituição quando a norma prevista no tratado for mais benéfica; (ii) impossibilitar a denúncia do tratado agora protegido como cláusula pétrea. ${ }^{104}$

\footnotetext{
99 MELO, Juliane Andréa de Mendes Hey; BONATO, Ariadne da Silveira. Cláusula de abertura dos direitos fundamentais... Op. Cit., p. 300.

100 SARLET, Ingo Wolfgang. Considerações... Op. Cit., p. 342.

101 PIOVESAN, Flávia. Direitos humanos e o Direito... Op. Cit., p. 138.

102 SCHIER, Paulo Ricardo. Hierarquia Constitucional dos Tratados... Op. Cit.

103 PIOVESAN, Flávia. Direitos humanos e o Direito... Op. Cit., p. 139.

104 EMERIQUE, Lilian Balmant; GUERRA, Sidney. A incorporação dos tratados internacionais de direitos humanos na ordem jurídica brasileira. Revista Jurídica, Brasília, v. 10, n. 90, p.1-34, abr./maio, 2008. p. 24.
} 
Valerio Mazzuoli e André de Carvalho Ramos discordam da segunda consequência. Para o primeiro, a impossibilidade de renúncia do tratado de direitos humanos existiria tanto para os tratados incorporados na forma do $\$ 2^{\circ}$ do art. $5^{\circ}$ quanto na forma do $\S 3^{\circ}$. O fato de serem materialmente constitucionais já impediria a denúncia dos tratados de direitos humanos incorporados, porque teriam se tornado cláusula pétrea. A diferença nos regimes, segundo Mazzuoli, estaria na consequência interna atribuída à denúncia pelo Presidente: no caso dos tratados materialmente constitucionais, o Presidente não estaria sujeito a crime de responsabilidade, porque o tratado não integrou formalmente a Constituição, não incidindo o art. 85, caput e inciso III da Constituição. Ao contrário, o Presidente cometeria crime de responsabilidade caso denunciasse o tratado de direitos humanos que fosse material e formalmente constitucional, já que neste caso tentou abolir cláusula pétrea constante do bloco de constitucionalidade. ${ }^{105}$ Por isso, para esse autor, a interpretação sistemática do art. $5^{\circ}, \S \S 2^{\circ}$ e $3^{\circ}$ admite a incorporação de tratados materialmente constitucionais e tratados material e formalmente constitucionais, e neste último caso as consequências da recepção equivalente a emenda constitucional seriam: (i) reforma do texto da Constituição; (ii) ocorrência de crime de responsabilidade do Presidente da República em caso de denúncia do tratado (art. 85 da Constituição); ${ }^{106}$ (iii) inserção das regras do tratado no conjunto de normas parâmetro para elaboração do controle concentrado de convencionalidade (art. 103 da Constituição). ${ }^{107}$

Já para André de Carvalho Ramos, a denúncia de tratados de direitos humanos no Brasil seria vedada em decorrência da proibição do retrocesso. ${ }^{108}$ Pela tese, controversa, não poderia o país retroceder a níveis superados de proteção incipiente de direitos humanos denunciando tratados. Assim, a denúncia estaria proibida e normas de tratados de direitos humanos estariam irrevogavelmente incorporadas no ordenamento jurídico, o que não deixa de ser contraditório com os próprios dispositivos de tratados de direitos humanos que regulamentam o processo de denúncia. ${ }^{109}$

\footnotetext{
105 MAZZUOLI, Valerio de Oliveira. Curso... Op. Cit., p. 922-923.

106 Idem, p. 915.

107 É justamente pelo fato de que compete ao Supremo Tribunal Federal a guarda da Constituição que, em relação aos tratados incorporados formalmente à Lei Fundamental, é possível o controle concentrado de convencionalidade. "Então, pode-se dizer que os tratados de direitos humanos internalizados pelo rito qualificado do art. $5^{\circ}, \S 3^{\circ}$, da Constituição passam a servir de meio de controle concentrado (agora de convencionalidade) da produção normativa doméstica, para além de servirem como paradigma para o controle difuso". (MAZZUO$\mathrm{LI}$, Valerio de Oliveira. Teoria geral do controle de convencionalidade no direito brasileiro. Revista de Informação Legislativa, Brasília, a. 46, n. 181, p. 113-139, jan./mar. 2009. p. 133).

108 RAMOS, André de Carvalho. Curso... Op. Cit., p. 401.

109 A exemplo do que prevê, por exemplo, o art. 78 da Convenção Americana sobre Direitos Humanos. A norma permite a denúncia da Convenção, que foi realizada pela Venezuela em 2012 em processo de denúncia acatado pela Corte Interamericana.
} 
Seja como for, a dita "equivalência" dos tratados mencionada no art. 5०, $\S 3^{\circ} \mathrm{diz}$ respeito à integração dos tratados de direitos humanos ao bloco de constitucionalidade. ${ }^{110}$ Eis aí a maior consequência da formalização dos tratados de direitos humanos: a incorporação da norma ao bloco de constitucionalidade "faz com que a origem internacional pública da nova ordem suprema seja sempre e de plano reconhecível".111 O tratado, ainda que não modifique o texto da Constituição, adere ao bloco e transmuta as normas materialmente constitucionais. ${ }^{112}$

Haveria, portanto, diferença entre os tratados equivalentes a normas constitucionais integrados no ordenamento segundo o rito do $\S 3^{\circ}$ do art. $5^{\circ}$ (norma do constituinte derivado) e os tratados com status constitucional recepcionados pelo art. $5^{\circ}$, $\$ 2^{\circ}$ (uma norma do constituinte originário). Uma vez que a norma do art. $5^{\circ}, \S 2^{\circ}$ da Constituição é produto do constituinte originário, tratados recepcionados de acordo com ela e que conflitassem com as normas da Constituição deveriam ser interpretados de modo a compatibilizar as normas. Afinal, foi uma opção do constituinte abrir o catálogo para normas de direitos humanos. ${ }^{113}$

Por sua vez, se alguma norma recepcionada de acordo com o rito do art. 5०, §3॰ conflita com os direitos fundamentais previstos na Constituição, ela seria materialmente inconstitucional, ${ }^{114}$ porque a norma é produto do Constituinte derivado e não pode afrontar cláusulas pétreas. ${ }^{115}$

De outro lado, a interpretação sistemática a favor da hierarquia constitucional dos tratados de direitos humanos coloca-se contra o argumento de que existem outras normas constitucionais que implicitamente indicam a hierarquia legal dos tratados de direitos humanos. A previsão de cabimento de recurso extraordinário contra decisão

\footnotetext{
110 Sobre a noção de bloco de constitucionalidade, ver: FERREIRA, Rafael Fonseca; LIMBERGER, Têmis Um diálogo sobre a autonomia da constituição e os direitos humanos: aproximações hermenêuticas a noção de bloco de constitucionalidade. Revista de Investigações Constitucionais, Curitiba, vol. 5, n. 1, p. 317-330, jan./abr. 2018; HACHEM, Daniel Wunder; PETHECHUST, Eloi. O direito humano à comunicação prévia e pormenorizada das acusações nos processos administrativos: O desprezo do Superior Tribunal de Justiça ao Pacto de San José da Costa Rica e à Corte Interamericana de Direitos Humanos. Revista de Direito Internacional, Brasília, v. 12, n. 2, p. 589-610, 2015.

111 MARTINS, Leonardo; MOREIRA, Thiago Oliveira. Controle de convencionalidade de atos do Poder Público: concorrência ou hierarquia em face do controle de constitucionalidade. In: PAGLIARINI, Alexandre Coutinho; DIMOULIS, Dimitri (Coord.). Direito Constitucional e Internacional dos Direitos Humanos. Belo Horizonte: Fórum, 2012. p. 296.

112 MOREIRA, Thiago Oliveira. A aplicação dos tratados... Op. Cit., p. 167.

113 Idem, p. 168.

114 A declaração de inconstitucionalidade, porém, só existirá em caso de conflito insolúvel. Na maioria das vezes não haveria colisão de direitos previstos constitucionalmente e no tratado. Em vários deles há concorrência, isto é, possibilidade de compatibilização das normas. Em todo caso, controvérsia na aplicação de direitos de mesma hierarquia previstos em tratado e Constituição se resolve a partir da teoria dos limites dos direitos fundamentais, mais precisamente a partir do critério da proporcionalidade (Cf. MARTINS, Leonardo; MOREIRA, Thiago Oliveira. Controle de convencionalidade... Op. Cit., p. 311).
}

115 MOREIRA, Thiago Oliveira. A aplicação dos tratados... Op. Cit., p. 168. 
que julgar inconstitucional tratado não impede tampouco o reconhecimento da constitucionalidade material de tratados. O mesmo em relação aos recursos especiais cabíveis, como já explicado. $\mathrm{O}$ art. 102 e art. 105 da Constituição não podem ser lidos isoladamente, descuidando da previsão do art. 5०, §2 e olvidando da diferença entre tratados comuns e tratados de direitos humanos. ${ }^{116}$ Os recursos extraordinário e especial, portanto, só caberiam em face de decisões sobre tratados comuns.

Do exposto, observa-se que, em relação à tese da hierarquia constitucional dos tratados de direitos humanos, a defesa da constitucionalidade material de todos os tratados radica na norma do art. $5^{\circ}, \S 2^{\circ}$, enquanto o art. $5^{\circ}, \S 3^{\circ}$ viria somente reforçar 0 regime jurídico ao contribuir para a constitucionalidade também formal das normas. Além do mais, a maior legitimidade democrática desses tratados quando passam pelo rito de aprovação de emendas é fator de relevância tanto no plano interno quando internacional. ${ }^{117}$ Assim, para a terceira corrente apresentada, os tratados incorporados na forma do art. $5^{\circ}, \S 3^{\circ}$ gozariam do mesmo regime protetivo dos tratados de direitos humanos: um regime mais reforçado.

\subsection{Hierarquia Supraconstitucional dos tratados internacionais de direitos humanos}

Em termos de valorização do Direito Internacional dos Direitos Humanos, a terceira corrente só não é mais prestigiada do que aquela que defende a supraconstitucionalidade dos tratados de direitos humanos. A corrente da supraconstitucionalidade, embora seja majoritária na jurisprudência das Cortes internacionais, conta com poucos adeptos na doutrina brasileira. Jaime Orlando Santofimio Gamboa lembra que nos casos Última Tentação de Cristo vs. Chile; ${ }^{118}$ Hilare, Constantine, Benjamin e outros vs.

116 SARLET, Ingo Wolfgang. Considerações... Op. Cit., p. 339.

117 SARLET, Ingo Wolfgang. Considerações... Op. Cit., p. 331.

118 No caso, paradigmático por contrapor um tratado a uma Constituição, a Corte IDH decidiu que o dispositivo constitucional que previa a censura prévia de espetáculos cinematográficos no Chile era contrário à Convenção, por afrontar o direito à liberdade de expressão do art. 13. Condenou ainda o Estado a alterar sua Lei Fundamental para adequá-la às obrigações internacionais assumidas. (CORTE INTERAMERICANA DE DIREITOS HUMANOS. Caso A Última Tentação de Cristo vs. Chile. Publicado em 5 fev. 2001). 
Trinidad e Tobago; ${ }^{119}$ Caesar vs. Trinidade e Tobago; ${ }^{120}$ Boyce e outros vs. Barbados ${ }^{121} \mathrm{e}$ Dacosta Cadogan vs. Barbados ${ }^{122}$ ficou claro que a questão da hierarquia dos tratados fica de lado quando a Corte IDH decide a convencionalidade de uma norma. Pouco importa se a norma é constitucional, pois, para a Corte, se ela desrespeita algum preceito da Convenção ela é anticonvencional e deve ser afastada, o que atribui ao tratado status supraconstitucional. ${ }^{123}$ É a relevância das normas de direitos humanos que satisfaria a condição necessária para posicioná-las no topo da hierarquia legal.

As críticas a essa quarta corrente são uma constante. A mais contundente afirma que colocar os tratados de direitos humanos acima da Constituição encontraria óbice no princípio da supremacia constitucional. ${ }^{124}$ A própria Constituição brasileira afastaria esse entendimento ao albergar preceitos sobre o controle de constitucionalidade dos tratados (art. 102, III, "b") e sobre o processo legislativo de sua incorporação (art. 49, I e 84, IV). ${ }^{125}$ Note-se que neste ponto o argumento é o mesmo dos defensores da hierarquia legal dos tratados. Mas além disso, para os críticos nem mesmo a afirmação da natureza especial e da relevância dos direitos humanos no contexto atual serviria de argumento. Segundo Gilmar Mendes, a vagueza dos dispositivos dos tratados e a possibilidade de atribuir a diversos deles natureza de tratado de direitos humanos colocaria em risco a posição da Constituição no topo da pirâmide normativa, ${ }^{126}$ já que os direitos nela previstos seriam superiores aos direitos originários do plano internacional.

A crítica não resiste a uma análise mais atenta. Em oposição ao argumento de Gilmar Mendes de que na expressão "direitos humanos" poderia caber qualquer

\footnotetext{
119 Neste caso, a Corte IDH considerou anticonvencional por afronta ao art. 4 da Convenção Americana a Lei de Delitos contra a Pessoa de Trinidade e Tobago, de 1925, por determinar a aplicação obrigatória de pena de morte na hipótese de homicídio doloso. (CORTE INTERAMERICANA DE DIREITOS HUMANOS. Caso Hilaire, Constantine e Benjamin e outros vs. Trinidade e Tobago. Publicado em 27 nov. 2003. § 103).

120 A Corte IDH neste caso julgou anticonvencional a Lei de Penas Corporais de Trinidade e Tobago que considerava lícita a ordem de Tribunais nacionais de aplicar a homens penas corporais. Os flagelos admitidos pela legislação interna foram declarados contrários à Convenção por afronta ao art. 5, sobre o direito à integridade corporal. (CORTE INTERAMERICANA DE DIREITOS HUMANOS. Caso Caesar vs. Trinidade e Tobago. Publicado em 11 mar. 2005).

121 Neste caso foi declarada contrária à Convenção Americana a Lei de Delitos contra as Pessoas de Barbados, de 1994, que impunha a pena de morte. A lei interna afrontou, de acordo com o julgado internacional, o art. 4 do Pacto de São José da Costa Rica. (CORTE INTERAMERICANA DE DIREITOS HUMANOS. Caso Boyce e outros vs. Barbados. Publicado em 20 nov. 2007).

122 Igualmente, a Corte IDH considerou a legislação sobre pena de morte contrária à Convenção de que é intérprete. (CORTE INTERAMERICANA DE DIREITOS HUMANOS. Caso Dacosta Cadogan vs. Barbados. Publicado em 24 set. 2009).

123 SANTOFIMIO GAMBOA, Jaime Orlando. El concepto de convencionalidad... Op. Cit., p. 255-256.

124 MENDES, Gilmar Ferreira. A supralegalidade dos tratados... Op. Cit., p. 223.

125 Idem, p. 224.

126 “(...) sempre possível ampliação inadequada dos sentidos possíveis da expressão 'direitos humanos' poderia abrir uma via perigosa para uma produção normativa alheia ao controle de sua compatibilidade com a ordem constitucional interna. O risco de normatizações camufladas seria permanentes". (MENDES, Gilmar Ferreira. A supralegalidade... Op. Cit., p. 224).
} 
conteúdo, fator incompatível com a dignidade de direitos fundamentais de hierarquia constitucional, Ingo Sarlet lembra que é suficiente a utilização de critérios hermenêuticos de apreensão dos significados. ${ }^{127}$ Nesse ponto não é preciso se alongar.

Em contraposição à defesa do princípio da supremacia constitucional, a questão está posicionada na relativização da soberania, tema já traçado, e da imprescindibilidade de outorgar às normas de proteção do ser humano a maior efetividade possível. Nesse sentido é que para Celso Duvivier de Albuquerque Mello, em atenção à jurisprudência internacional e ao princípio pro persona, as normas de tratados internacionais de direitos humanos incorporadas no Brasil seriam dotadas de hierarquia supraconstitucional. ${ }^{128}$

Apesar da utilidade prática da teoria constitucional, o paradigma pós-estadualista na realidade põe em dúvida alguns dos postulados aos quais o jurista assenta seu ponto de partida. O Direito estatal sofre de rupturas identificadas na prática. Essas tensões estão cada vez mais elastecidas e não parece indicado resistir à tendência humanista. ${ }^{129}$ A defesa da supraconstitucionalidade não se baseia só na natureza privilegiada da norma de Direito Internacional dos Direitos Humanos, conquanto essa seja a principal defesa do argumento. Ela se baseia também na voluntariedade. Isto é, no

\footnotetext{
127 "Eventuais distorções - assim como ocorrem em casos de inadequada aplicação até mesmo dos direitos consagrados na Constituição (que, não esqueçamos, incluem os previstos nos tratados, consoante dicção expressa do art., $5^{\circ}, \S 2^{\circ}$ ) - haverão de ser superados, com sensibilidade, pela aplicação das cabíveis diretrizes hermenêuticas, como é o caso dos critérios da concordância prática, ponderação e proporcionalidade". (SARLET, Ingo Wolfgang. Considerações... Op. Cit., p. 339).

128 In verbis: "A Constituição de 1988 no $\$ 2$ do art. $5^{\circ}$ constitucionalizou as normas de direitos humanos consagradas nos tratados. Significando isto que as referidas normas são normas constitucionais, como diz Flávia Piovesan citada acima. Considero esta posição já como um grande avanço. Contudo sou ainda mais radical no sentido de que a norma internacional prevalece sobre a norma constitucional, mesmo naquele caso em que uma norma constitucional posterior tente revogar uma norma internacional constitucionalizada. A nossa posição é a que está consagrada na jurisprudência e tratado internacional europeu de que se deve aplicar a norma mais benéfica ao ser humano, seja ela interna ou internacional. A tese de Flávia Piovesan tem a grande vantagem de evitar que o Supremo Tribunal Federal venha a julgar a constitucionalidade dos tratados internacionais". (MELLO, Celso Duvivier de Albuquerque. O $\$ 2^{\circ}$ do art. $5^{\circ}$ da Constituição Federal. In: TORRES, Ricardo Lobo (Org.). Teoria dos Direitos Fundamentais. 2. ed. Rio de Janeiro: Renovar, 2001. p. 25).

129 "No plano teórico, torna-se difícil continuar a sustentar que a constituição do Estado ocupe o topo de uma pirâmide de normas que incluiria também os direitos não estaduais. Nomeadamente porque, em relação às normas jurídicas não estaduais, não é teoricamente fácil explicar como e onde é que elas seriam incluídas nesta pirâmide cujo topo seria a constituição do Estado. Realmente, uma visão pluralista da superfície do direito descreveria esta, não tanto como uma pirâmide de normas, mas antes como uma 'cordilheira' de várias pirâmides, uma das quais seria o direito oficial, outras compreendendo a conjuntos - eventualmente também hierarquizados - de normas não estaduais. Constituiria, porém, uma forma inaceitável de conceitualismo ou de formalismo partir desse argumento teórico para resolver definitivamente um problema que tem também dimensões práticas, pois a bondade da resposta depende também das suas consequências práticas, avaliadas do ponto de vista da democraticidade do direito, que aqui tem sido aproximada da sua capacidade de satisfazer expectativas geralmente consensuais". (HESPANHA, Antonio Manuel. Pluralismo jurídico... Op. Cit., p. 248).
} 
princípio segundo o qual a adesão a um tratado derroga qualquer disposição de Direito interno. ${ }^{130}$

O art. 27 da Convenção de Viena (incorporada no Direito brasileiro, como se viu acima) nada mais faz do que reconhecer o princípio da primazia do Direito Internacional, usualmente posto em patamar privilegiado pela doutrina internacionalista. ${ }^{131} \mathrm{~A}$ jurisprudência internacional e a Convenção de Viena de 1969 nos artigos 26 e 27 excluem a possibilidade de o Estado invocar razões de Direito interno para escusar-se de obrigações internacionais, o que leva ao entendimento da hierarquia supraconstitucional de qualquer tratado. André Gonçalves Pereira e Fausto de Quadros investigaram ainda os documentos dos trabalhos preparatórios da Convenção de Viena ${ }^{132}$ para consignar que a norma do art. 27 foi proposta pela delegação do Paquistão "com a intenção declarada de impedir que os Estados invocassem a respectiva Constituição a fim de se subtraírem ao cumprimento dos tratados por eles livremente concluídos".133

Mas mesmo que seja verdade que a tese esbarra nos dispositivos expressos na Constituição que assumem, a partir de uma leitura enviesada, a hierarquia infraconstitucional de tratados, também é verdade que a Constituição - ao menos a brasileira - em normas como aquela do art. 4ㅇ, II dá primazia aos direitos humanos e tem no art. $5^{\circ}, \S 2^{\circ}$ sua cláusula de abertura.

O Direito Internacional dos Direitos Humanos e o Direito nacional estão integrados em virtude das próprias normas consagradas na Constituição brasileira. Para além da polêmica entre dualistas e monistas, o fato é que a jurisprudência internacional aceita a primazia da norma internacional, ${ }^{134}$ e reconhecer que o Direito é um só é a direção coerente com os tempos de integração econômica e social. ${ }^{135}$

Para Agustín Gordillo, as normas supranacionais instituidoras de garantias mínimas aos cidadãos do mundo devem se sobrepor às regulamentações internas, não importa qual for a hierarquia da norma. Segundo o autor, esse é o preço a pagar pela

\footnotetext{
130 SILVA, Caíque Tomaz Leite; OLIVEIRA, Carlos Eduardo Sindona de. O décimo aniversário da emenda 45... Op. Cit., p. 142-143.

131 "É este um princípio que rege as obrigações internacionais, um princípio de responsabilidade internacional e mesmo de direito costumeiro: um Estado não pode evadir-se de suas obrigações internacionais sob o pretexto de sua pretensa incompatibilidade com o seu ordenamento jurídico interno (ou quaisquer atos emanados do poder público - legislativos, executivos ou judiciais)". (TRINDADE, Antônio Augusto Cançado. A humanização... Op. Cit., p. 44).

132 Lembre-se que, caso se compreenda a Convenção de Viena uma norma de jus cogens internacional ou norma integrada no costume internacional com status supraconstitucional, é possível até mesmo sustentar a derrogação dos dispositivos constitucionais sobre controle de constitucionalidade de tratados e prevalência de qualquer norma de Direito Internacional perante a Constituição. (PEREIRA, André Gonçalves; QUADROS, Fausto de. Manual... Op. Cit., p. 123).

133 Idem, p. 120. Grifos no original.

134 MELLO, Celso D. de Albuquerque. Curso... Op Cit., p. 127.

135 Idem, p. 135.
} 
convivência pacífica e ordeira no mundo atual. ${ }^{136}$ Ademais, há um fundamento lógico na atribuição de supraconstitucionalidade às normas de direitos humanos previstas em tratados: "Não tem sentido decidir pela submissão a uma ordem jurídica supranacional, e a um tribunal com competência formal para aplicá-la e sancionar ao descumpridor, para logo pretender a suposta supremacia da ordem local sobre a ordem internacional".137 A supraconstitucionalidade de uma norma poderia ainda ser fundamentada em objetivos relevantes do Estado Constitucional e Humanista de Direito, com as seguintes características: (i) orientação de suas ações fundada na ética da alteridade; (ii) reconhecimento da diversidade cultural existente no mundo; (iii) desnecessidade de aceite dos Estados para obrigarem-se às regras universais; (iv) consagração de uma "justiça planetária"; (v) quebra o conceito de soberania estatal; (vi) contribuição para o avanço civilizatório da humanidade. ${ }^{138}$

É preciso cautela no entendimento de que o reconhecimento da hierarquia supraconstitucional dos tratados de direitos humanos levaria ao fim do princípio da supremacia da Constituição. Não se nega que pode enfraquecer o princípio, mas não o anula, uma vez que desde o início do constitucionalismo o objetivo do movimento coincide com a finalidade do Direito Internacional dos Direitos Humanos, qual seja, "resguardar a pessoa humana em sua convivência política".139 E mesmo que o reconhecimento da hierarquia supraconstitucional dos tratados internacionais de direitos humanos dependa do reconhecimento desta condição pelo ordenamento interno, ${ }^{140}$ normas previstas em tratados de direitos humanos classificadas como jus cogens têm sempre hierarquia supraconstitucional, ${ }^{141}$ o que nunca foi necessariamente um problema para a soberania estatal.

Aliás, é curioso notar que o Supremo Tribunal Federal, ao passo que se posicionou por maioria pela supralegalidade dos tratados de direitos humanos, ao editar a Súmula Vinculante n. 25 terminou por esvaziar o conteúdo de uma norma constitucional que permite ao menos uma modalidade de prisão por dívidas. Na prática, a par da construção da tese da "eficácia paralisante" dos tratados, pode se dizer que houve um reconhecimento (ainda que não manifesto) do status supraconstitucional da Convenção Americana sobre Direitos Humanos, na medida em que houve um bloqueio indireto

\footnotetext{
136 GORDILLO, Agustín Alberto et al. Derechos humanos... Op. Cit., p. III-7-8.

137 Idem, p. III-7.

138 GOMES, Luiz Flávio; MAZZUOLI, Valerio de Oliveira. Direito Supraconstitucional... Op. Cit., p. 166-173.

139 CAMPOS, Germán J. Bidart. Teoría general de los derechos humanos. Buenos Aires: Editorial Astrea de Alfredo y Ricardo Depalma, 1991. p. 353.

140 lbidem.

141 GALINDO, George Rodrigo Bandeira. Tratados Internacionais de Direitos Humanos e Constituição Brasileira. Belo Horizonte: Del Rey, 2002. p. 319-321; PEREIRA, André Gonçalves; QUADROS, Fausto de. Manual... Op. Cit., p. 118.
} 
da norma constitucional por aplicação de tratado. ${ }^{142}$ Ou seja, na prática jurisprudencial brasileira já se estabeleceu - ainda que de forma incipiente, enviesada e não expressa, é verdade - a prevalência da norma internacional sobre a norma constitucional, ainda que pela via interpretativa. Esse fato é exemplificativo da tendência doutrinária e jurisprudencial cada vez mais frequente de admissão da existência de normas superiores àquelas previstas na Constituição.

\section{RELATIVIZAÇÃO DO CRITÉRIO HIERÁRQUICO DE ORDENAÇÃO DAS NORMAS: HIERARQUIA SUPRACONSTITUCIONAL A PRIORI DOS TRATADOS INTERNACIONAIS DE DIREITOS HUMANOS}

Aos poucos, o paradigma do princípio da supremacia absoluta da Constituição cede à normas de Direito Internacional de Direitos Humanos, jus cogens ou não. Diante disso, e por isso mesmo é que se adere à doutrina da supraconstitucionalidade das normas previstas em tratados internacionais de direitos humanos incorporadas no Direito brasileiro, embora a proposta aqui seja de defesa da supraconstitucionalidade a priori ou relativa.

Supraconstitucionalidade relativa porque a solução hierarquizante para solução de conflitos não é absoluta. Ela cede ao critério pro persona e às interpretações jurisprudenciais internacionais e nacionais vinculantes aos Poderes de Estado. ${ }^{143}$ Afinal, quando se trata de definir questões que envolvem o Direito Internacional dos Direitos Humanos, no fim das contas é equivocado falar em prevalência do Direito interno sobre o Direito Internacional, ou vice-versa. Diante da percepção de uma solução menos benéfica ou pior para o ser humano em caso de prevalência da norma de maior hierarquia na solução do caso, caberá ao operador desconsiderar o grau hierárquico da norma e privilegiar a opção mais protetiva à pessoa. ${ }^{144}$ Resumidamente, o critério é o seguinte: para reconhecer direitos, procede-se na interpretação ou aplicação mais ampla da norma, e para limitar direitos na interpretação ou aplicação mais restrita da norma. Apelidou-se o instituto que regula essa técnica de princípio pro persona, pro homine, ou princípio da primazia da norma mais favorável. ${ }^{145}$ Designa-se princípio (e não regra) pro persona com base nos dois principais critérios de distinção de normas entre princípios e regras

\footnotetext{
142 SARLET, Ingo Wolfgang. Considerações... Op. Cit., p. 344.

143 O princípio pro persona foi reconhecido como critério de interpretação pela Corte IDH no Caso A Última Tentação de Cristo vs. Chile, em 2001. CORTE INTERAMERICANA DE DIREITOS HUMANOS. Caso A Última Tentação de Cristo... Op. Cit.

144 GONZÁLEZ MORAS, Juan M. La internacionalización del Derecho Administrativo argentino. Revista Argentina del Régimen de la Administración Pública, a. XXIX, n. 348, Buenos Aires, Ediciones RAP, p. 15-53, set. 2007. p. 17.

145 Conquanto a doutrina use as expressões indistintamente, o trabalho dá preferência à expressão "princípio pro persona", mais inclusiva do que expressões que poderiam dar a impressão de redução do princípio à proteção do ser humano do gênero masculino (v.g. princípio pro homine).
} 
adotados pela doutrina brasileira, isto é, tanto com fulcro no critério da fundamentalidade, quanto com arrimo no critério do modo de aplicação. ${ }^{146}$ Neste trabalho, no entanto, o princípio pro persona é designado assim dado o seu grau de importância para o Direito Internacional dos Direitos Humanos.

Diante do princípio pro persona, a relevância da hierarquia conferida às normas jurídicas diminui. Em outras palavras, o critério da hierarquia torna-se "flexível". Até mesmo em conflitos entre tratados e a Constituição, em função do objetivo que anima o Direito Internacional dos Direitos Humanos, sempre prevalecerá a norma mais favorável ao sujeito de direito. ${ }^{147}$ Formalmente, o ordenamento ainda é uma pirâmide, mas materialmente as normas seguem a lógica da prevalência da norma mais protetiva. Por essa razão, a expressão técnica mais adequada para o fenômeno jurídico que ocorre nos casos de aparente conflito de normas não é "revogação", pois o que acontece na verdade é simplesmente o afastamento das normas menos protetivas nos casos concretos, sem que elas sejam extirpadas do ordenamento. ${ }^{148}$ A solução aproxima-se daquilo que o Supremo Tribunal Federal já designou de eficácia paralisante das normas internacionais.

Para que o princípio não seja utilizado de modo a privilegiar argumentos opostos com a mesma força, há três critérios para sua aplicação: (i) Aplicação da norma mais protetiva: independentemente da hierarquia da norma, diante de disposições conflitantes o aplicador deve privilegiar o dispositivo mais favorável ao indivíduo ou vítima. O critério vale entre normas internacionais conflitantes ou entre uma norma internacional e outra nacional. Os problemas técnicos a enfrentar no âmbito desse critério surgem quando o intérprete precisa optar no conjunto pela norma mais favorável, ou

\footnotetext{
146 A definição do que é princípio para o Direito admite critérios diferenciados. Entre os mais utilizados pela doutrina brasileira, dois deles merecem referência. O primeiro critério é o do grau de fundamentalidade, segundo o qual uma norma é considerada princípio e se diferencia das regras pelo seu grau de importância no sistema jurídico. A importância de que um princípio se reveste permitirá verificar o modo de funcionamento de um sistema jurídico e de seus ramos, a compatibilidade de normas com o sistema e inclusive derivar normas desse sistema. É expoente dessa corrente o administrativista Celso Antônio Bandeira de Mello, que define princípios como "mandamento nuclear do sistema, verdadeiro alicerce", base da qual se orienta para interpretar e aplicar as normas peculiares de um ramo do Direito. (MELLO, Celso Antônio Bandeira de. Curso de Direito Administrativo. 33. ed. São Paulo: Malheiros, 2016. p. 54). O segundo critério de definição aqui mencionado (e de diferenciação entre princípios e regras) é o critério lógico-estrutural. Segundo esse critério, o que distingue um princípio de uma regra é um dado lógico: possuem estrutura diferenciada e forma de aplicação distinta. A natureza de cada uma das normas varia segundo sua estrutura e seu modo diferenciado de aplicação, o que permite diferenciar igualmente o modo de resolução de conflitos entre essas diferentes espécies de normas. São expoentes dessa corrente Ronald Dworkin e Robert Alexy. Para ambos, pouco importa o grau de fundamentalidade da norma para sua classificação como princípio (DWORKIN, Ronald. Levando os direitos a sério. São Paulo: Martins Fontes, 2002. p. 36; ALEXY, Robert. Teoria dos Direitos Fundamentais. Trad. Virgílio Afonso da Silva. São Paulo: Malheiros. 2015. p. 29). Para explicação teórica sobre os dois modelos e sua possibilidade de convivência no Direito Administrativo brasileiro, cf. HACHEM, Daniel Wunder. Princípio constitucional da supremacia do interesse público. Belo Horizonte: Fórum, 2011.
}

147 GOMES, Luiz Flávio; MAZZUOLI, Valerio de Oliveira. Direito Supraconstitucional... Op. Cit., p. 112-113.

148 Idem, p. 119. 
quando precisa decidir se aplica artigos de cada norma em separado de modo a conjugar o melhor dos mundos para o destinatário; (ii) Conservação da norma mais protetiva: quando uma norma é revogada tácita ou expressamente por norma posterior, esse critério interpretativo indica que, não obstante o comando legal, prevalece a norma anterior caso seja mais favorável ao indivíduo ou à vítima. O brocardo lex posteriori derogat priori é afastado, como se os termos da questão fossem alterados e um problema de revogação fosse convertido em um problema hermenêutico; (iii) Interpretação protetiva: esse critério se aplica quando o intérprete está diante de uma única norma (e não duas ou mais), e existem vários sentidos possíveis a serem conferidos à lei ou ao tratado. Nesse caso, o critério hermenêutico da interpretação protetiva demanda a escolha do sentido que proteja melhor o indivíduo ou vítima, ressalvada a proibição de conferir interpretação contrária à finalidade da norma eleita pelo legislador ou prevista no tratado internacional. ${ }^{149}$

Se apenas parcela da norma for mais favorável, é lícito ao “intérprete, aplicar ambas as normas aparentemente antinômicas conjuntamente, cada qual naquilo que têm de melhor à proteção do direito da pessoa, sem que precise recorrer aos conhecidos (e, no âmbito dos direitos humanos, ultrapassados) métodos tradicionais de solução de antinomias (o hierárquico, o da especialidade e o cronológico)".150 A consagração do princípio pro persona tem, portanto, como consequências: (a) a redução de potenciais conflitos normativos; (b) maior coordenação entre normas na dimensão vertical entre tratados e normas internas; (c) a maior coordenação entre normas na dimensão horizontal entre dois ou mais tratados. ${ }^{151}$

A expansão do Direito Internacional dos Direitos Humanos e da principiologia pro persona, bem como a necessidade premente de intensificação de proteção do ser humano e do meio ambiente do qual o ser humano faz parte já seriam motivos fortalecedores da tese da derrogação de normas constitucionais em caso de conflito insanável, situação que só se constata após a utilização de técnicas hermenêuticas e de compatibilização de normas. Mas, em atenção à natureza deste estudo, a principal razão para admissão da corrente da supraconstitucionalidade relativa é dogmática, calcada em uma interpretação das decisões tomadas pelo constituinte brasileiro e traduzida em disposições constitucionais.

Foi a própria Constituição brasileira que desde sua promulgação admitiu a supraconstitucionalidade dos tratados de direitos humanos devidamente incorporados. Em primeiro lugar, a hierarquia supraconstitucional dos tratados de direitos humanos encontra fundamento no art. $5^{\circ}, \S 2^{\circ}$ da Constituição. Se de acordo com a regra os

149 HENDERSON, Humberto. Los tratados internacionales... Op. Cit., p. 93-95.
150 MAZZUOLI, Valerio de Oliveira. Curso... Op. Cit., p. 900.
151 TRINDADE, Antônio Augusto Cançado. Tratado de Direito... Op. Cit., p. 544. 
direitos fundamentais expressos na Lei Fundamental não excluem outros direitos aplicáveis do Direito Internacional (outros direitos não listados nela e reconhecidos como fundamentais internacionalmente), isso quer dizer naquela cláusula de abertura a própria Constituição visou dar preferência ao regramento externo que ela não previu. ${ }^{152}$ Afirmar "não excluem" seria equivalente a dizer "dá preferência".

Em segundo lugar, desde que sigam o procedimento de incorporação, seja mediante aprovação por maioria simples ou qualificada no Congresso Nacional, os tratados de direitos humanos em vigor prevalecem sobre qualquer norma em virtude do comando do art. 4, II da Constituição. É dizer, a República Federativa do Brasil tem como princípio fundamental a prevalência dos direitos humanos nas relações internacionais. Ao admiti-lo, todo tratado internacional de direitos humanos incorporado na forma prevista constitucionalmente adere ao ordenamento jurídico brasileiro em plano superior ao constitucional, desde que mais favorável ao ser humano. ${ }^{153}$ É este um princípio fundamental da República em consonância com a jurisprudência internacional de Direito Internacional dos Direitos Humanos e com a perspectiva humanista retomada após a Segunda Guerra Mundial, agora mais necessária do que nunca diante das novas tecnologias que interligam os continentes e pessoas, dos conflitos emergentes no globo, do terrorismo e do problema ambiental.

Em terceiro lugar, uma vez que o princípio pro persona integra o ordenamento como modo qualificado de solução de conflitos, o status supraconstitucional a priori das normas de tratados de direitos humanos obriga uma interpretação convencionalmente adequada do art. 102, III, "b" e art. 105, III, "a" da Constituição. A norma do art. 102, III, "b" da Constituição, segundo a qual cabe recurso extraordinário ao Supremo Tribunal Federal quando decisão judicial de única ou última instância declarar inconstitucional tratado internacional, só vale para os tratados comuns. Isto é, se aplica somente a tratados internacionais que regulam outros aspectos da vida humana, como por exemplo tratados comerciais, territoriais, etc., os quais não são de direitos humanos e não têm hierarquia supraconstitucional, mas hierarquia supralegal (ou hierarquia legal, segundo a jurisprudência dominante no Supremo Tribunal Federal). Por sua vez, a norma do art. 105, III, "a" da Constituição, segundo a qual cabe recurso especial quando a decisão de única ou última instância contrariar ou negar vigência a tratado, desde que interpretada segundo critérios hermenêuticos de Direito Internacional de Direitos Humanos,

152 O argumento pertence a André Gonçalves Pereira e Fausto de Quadros e indica a natureza supraconstitucional dos tratados na ordem jurídica portuguesa. Mas se aplica perfeitamente ao caso brasileiro, pois o art. $5^{\circ}, \S 2^{\circ}$ da Constituição guarda similitude com o art. 16, n. 1 da Constituição portuguesa. Cf. PEREIRA, André Gonçalves; QUADROS, Fausto de. Manual... Op. Cit., p. 117.

153 Mesmo nos países que adotam a tese da supralegalidade dos tratados, o princípio pro persona permite que uma lei posterior prevaleça sobre a disposição do tratado de direitos humanos quando aquela for mais favorável ao indivíduo ou menos restritiva de sua esfera jurídica. Apesar de inferior em hierarquia, neste caso a lei torna inaplicável o tratado. Cf. HENDERSON, Humberto. Los tratados internacionales... Op. Cit., p. 80-81. 
indica o cabimento de dito recurso ao Superior Tribunal de Justiça quando qualquer tratado, seja ele comum ou de direitos humanos, for contrariado por decisão de tribunal ou este negar-Ihe vigência. Portanto, a solução da supraconstitucionalidade não contrasta com a Constituição.

\section{CONCLUSÃO}

A primazia da norma mais favorável como fundamento para hierarquia supraconstitucional dos tratados não está isenta de críticas. ${ }^{154}$ Especialmente, pode ser encarada como problemática para aqueles que defendem soluções não hierárquicas para solução de problemas envolvendo Direito Internacional dos Direitos Humanos. Não se nega que os tempos atuais são de sincretismo constitucional, realidade em que normas nacionais e internacionais são complementares. ${ }^{155}$ Nesse sentido, os autores transconstitucionalistas ${ }^{156}$ discorrem aprofundadamente sobre os perigos de definir hierarquias rígidas das normas.

Com apoio na teoria transconstitucional de Marcelo Neves, ${ }^{157}$ Marcelo Torelly indica o modo de relacionamento não hierárquico (heterárquico) das ordens jurídicas no contexto da governança transversal dos direitos fundamentais. O processo considera "a especial relevância que os problemas constitucionais têm no sistema jurídico, mas sem

154 Como nem mesmo o caráter autoritário e ativista das Cortes Internacionais em relação às suas decisões que partem da autoridade do princípio pro persona. Para uma introdução, cf. LEAL, Mônia Clarissa Henning. Corte Interamericana de Direitos Humanos e jurisdição constitucional: judicialização e ativismo judicial em face da proteção dos direitos humanos e fundamentais? Revista de Investigações Constitucionais, Curitiba, v. 1, n. 3, p. 123-140, set./dez. 2014.

155 SILVA, Caíque Tomaz Leite; OLIVEIRA, Carlos Eduardo Sindona de. O décimo aniversário da emenda 45... Op. Cit., p. 155.

156 Anderson Teixeira define o fenômeno transconstitucional do seguinte modo: "(...) o constitucionalismo global pode ser concebido, em termos gerais, como um processo global de afirmação da ubiquidade da existência humana como um bem em si, independentemente de concessões de direitos ou atribuições de sentido/significado estatais, que demanda reconhecimento de direitos não mais vinculados apenas a um Estado nacional específico e que termina redefinindo os objetivos finalísticos do próprio Estado, pois pressiona rumo a integração política internacional e promove, por um lado, diversas esferas transversais de normatividade, enquanto que, por outro, reforça o papel do Estado na proteção interna dos direitos individuais, na afirmação dos direitos culturais e na instrumentalização das políticas globais". (TEIXEIRA, Anderson Vichikesnki. Constitucionalismo transnacional... Op. Cit., p. 159).

157 O transconstitucionalismo admite "hierarquia entrelaçadas" de ordens jurídicas nacionais e nacionais e supranacionais (ou entre múltiplas ordens, o que acresce em complexidade a análise). As relações entre os sistemas, embora haja hierarquia dentro deles, são heterárquicas, nas quais nenhum deles detém a palavra final sobre o problema a resolver. A teoria parte do pressuposto de que os ordenamentos estão constituídos em "redes construtivas" de normas e sentidos, no que há aprendizado recíproco. Nesse sentido, cf. NEVES, Marcelo. Transconstitucionalismo. São Paulo: Martins Fontes, 2009; NEVES, Marcelo. Transconstitucionalismo: breves considerações com especial referência à experiência Latino Americana. In: ANTONIAZZI, Mariela Morales; BOGDANDY, Armin Von; PIOVESAN, Flávia (Coords.). Direitos humanos, democracia e integração jurídica: avançando no diálogo constitucional e regional. Rio de Janeiro: Lumen luris, 2011. p. 255-284; NEVES, Marcelo. (Não) Solucionando problemas constitucionais: transconstitucionalismo além de colisões. Lua Nova, São Paulo, v. 93, p. 201-232, 2014. 
determinar uma prevalência a priori do direito constitucional doméstico sobre o direito internacional dos direitos humanos ou vice-versa". ${ }^{158} \mathrm{~A}$ negativa de uma solução hierarquizante leva à retroalimentação das decisões pelas Cortes nacionais e internacionais, ${ }^{159}$ o que representa um processo de construção e reconstrução da jurisprudência sobre direitos humanos. ${ }^{160}$

No entanto, soluções heterárquicas do transconstitucionalismo e aquelas típicas dos diálogos jurisdicionais não são incompatíveis com o estabelecimento de critérios especiais de resolução de conflitos. Notadamente porque em face de um problema constitucional, imerso na diversidade das normas jurídicas, o aplicador do Direito obriga-se a, primeiramente, definir a priori qual a norma de maior hierarquia que prevalecerá e iluminará a interpretação das normas inferiores. O critério pro persona convive com essa proposta, relativizando-a e compreendendo até mesmo a utilidade da proposta heterárquica, possibilitando que o diálogo entre as Cortes aconteça sob o fundo comum da proteção máxima do ser humano.

O que se quer dizer é que mais importante do que definir a hierarquia dos tratados de direitos humanos, possivelmente seja estabelecer os métodos para um diálogo frutífero e efetivo em um contexto de pluralismo que depende inclusive de mecanismos de respeito às decisões de Cortes internacionais. ${ }^{161}$ Do mesmo modo, independentemente da técnica jurídica empregada (e aqui defende-se a utilidade e plena aplicabilidade do princípio pro persona), o importante é a aceitação do novo paradigma de cooperação entre Estados vivido, no qual os textos normativos se abrem às experiências externas e se legitimam na medida de seu comprometimento com as causas mundiais comuns. $^{162}$

Se o que une a humanidade é a condição idêntica dos indivíduos que a compõem, as normas protetivas dessa mesma condição devem se aplicar a todos os seres humanos indistintamente de modo a superar em hierarquia as normas estatais de países diferentes, sejam elas legais ou constitucionais. A relativização da soberania é o preço a ser pago para participar da comunidade global de nações, orientadas à

\footnotetext{
158 TORELLY, Marcelo. Governança transversal... Op. Cit., p. 99.

159 A retroalimentação das decisões é a consequência da perspectiva horizontal de um Direito Internacional dos Direitos Humanos aplicável segundo a lógica do Direito Comparado: "Como todas as linguagens, incluindo o Direito, refletem o mundo que seus falantes habitam, o que encontra expressão para um pode não encontrar ou ressoar no outro. Como uma forma de tradução, o Direito Comparado está atento ao fato de que uma lei estrangeira com frequência precisará ser adaptada". (KNOP, Karen. Here and there: International law in domestic courts. New York University Journal of International Law and Politics, New York. v. 32. n. 2, p. 501-535, 2000. p. 529).

160 TORELLY, Marcelo. Governança transversal... Op. Cit., p. 132.

161 RAMOS, André de Carvalho. Pluralidade das ordens jurídicas: uma nova perspectiva na relação entre o Direito Internacional e o Direito Constitucional. Revista da Faculdade de Direito da Universidade de São Paulo, São Paulo, v. 106/107, p. 497-524, jan./dez. 2011/2012. p. 522.

162 MALISKA, Marcos Augusto. Constituição e cooperação... Op. Cit., p. 120-121.
} 
proteção do ser humano e do meio ambiente com caráter prioritário. De outro lado, razões dogmáticas também respaldam a hierarquia supraconstitucional de normas de tratados de direitos humanos internalizados na ordem jurídica brasileira. Primeiramente, o preâmbulo da Constituição de 1988 consagra o reconhecimento da ordem jurídica interna e internacional como lócus primordial de solução pacífica das controvérsias às quais estão sujeitas todas as sociedades. Em segundo lugar, a interpretação sistemática de normas específicas previstas na Constituição segundo critérios hermenêuticos que favorecem a pessoa humana e lhes dão a maior eficácia possível (especialmente o princípio pro persona) levam ao mesmo entendimento. O art. 4, II da Constituição prevê que o Brasil se rege em suas relações internacionais pela prevalência dos direitos humanos, norma que denota a opção constituinte de privilegiar os direitos humanos no cenário internacional durante a assinatura e adesão a tratados. Por sua vez, o art. $5^{\circ}$ prevê para esses mesmos direitos um regime jurídico diferenciado. $\mathrm{O}$ art. $5^{\circ}, \S^{\circ}{ }^{\circ}$ prevê a aplicabilidade imediata deles, confirmando a jurisprudência dominante nas Cortes internacionais acerca do caráter auto-executável (self-executing) dos tratados de direitos humanos, técnica condizente com a busca de efetividade da proteção da pessoa humana. $\mathrm{O}$ art. $5^{\circ}, \S 2^{\circ}$ prevê que direitos e garantias expressos na Constituição não excluem outros decorrentes dos tratados internacionais em que a República Federativa do Brasil seja parte. Na medida em que esta regra de abertura afirma que direitos previstos no plano interno não excluem direitos do plano externo, ela visa a privilegiar aqueles direitos de origem internacional classificados como direitos humanos que a Constituição não previu, mas que têm caráter cronológico e lógico antecedente à própria edição da Constituição. Esta é a interpretação mais benéfica ao ser humano e mais compatível com o art. $4^{\circ}$, Il da Constituição.

A corrente supraconstitucional relativa de hierarquia de tratados de direitos humanos aqui defendida assume como válido e eficaz o art. 5०, § $3^{\circ}$ da Constituição. Ao aprovar o ingresso de algum tratado segundo um procedimento mais rigoroso e torná-lo equivalente a emenda constitucional, o Congresso brasileiro estaria integrando o tratado no bloco de constitucionalidade e permitindo o controle abstrato de constitucionalidade pelo Supremo Tribunal Federal. O art. $5^{\circ}, \S 3^{\circ}$ seria, portanto, regra de Direito Processual Constitucional tendente a ampliar as normas que servem de parâmetro para controle abstrato de constitucionalidade em ações típicas definidas na Constituição, o que de resto não impediria o controle de convencionalidade concreto pelo próprio Supremo Tribunal Federal e pelos demais juízes e tribunais. Além disso, ao incorporar-se com status de emenda constitucional o tratado estaria definitivamente protegido como cláusula pétrea, sendo vedada a partir de então sua denúncia. Ressalva-se que neste trabalho defende-se a possibilidade de denúncia de tratados de direitos humanos, desde que obedecido o procedimento definido pelas respectivas convenções. $A$ norma inserida pela Emenda Constitucional n. 45/2004, ao fim e ao cabo, estende o 
espectro de ações cabíveis para a defesa dos direitos humanos e aumenta o grau de proteção da pessoa humana.

Não bastassem esses argumentos, a hierarquia supraconstitucional dos tratados é a posição consolidada na jurisprudência internacional. Para as Cortes internacionais, a norma internacional de direitos humanos está acima das Constituições nacionais. A hierarquia definida nos ordenamentos internos para normas não convencionais é tomada como mero fato pelas Cortes internacionais, que buscam verificar em seus julgados a compatibilidade de qualquer norma interna com normas de tratados de direitos humanos integradas. A Corte Interamericana de Direitos Humanos confirmou esse entendimento, entre outros, no Casos Última Tentação de Cristo vs. Chile, de 2001. A posição da jurisprudência internacional tem como principal fundamento o princípio da boa-fé e o princípio costumeiro do pacta sunt servada, cuja natureza é de jus cogens. Norma positiva albergou esses princípios na Convenção de Viena sobre Direito dos Tratados, vigente no Brasil desde a publicação do Decreto n. 7.030/2009. A Convenção de Viena prevê no art. 26 que "Todo tratado em vigor obriga as partes e deve ser cumprido por elas de boa fé" e no art. 27 que "Uma parte não pode invocar as disposições de seu direito interno para justificar o inadimplemento de um tratado". A regra do art. 27 foi projetada para evitar que os Estados deixassem de cumprir as obrigações internacionais assumidas legitimamente e contempla na expressão "direito interno" inclusive as normas previstas nas Constituições. Não haveria sentido o Estado assumir uma obrigação internacional e a competência jurisdicional de Cortes de direitos humanos para posteriormente negar-lhes obrigatoriedade e vinculação a pretexto de preservar um esquema teórico ultrapassado de soberania nacional. Tamanha contradição não é admitida como interpretação válida perante o Direito Internacional Público e muito menos perante o Direito Internacional dos Direitos Humanos.

A supraconstitucionalidade das normas previstas em tratados internacionais de direitos humanos incorporadas no Direito brasileiro e das normas definidas costumeiramente como jus cogens, cumpre salientar, é relativa. Perante o Direito Internacional dos Direitos Humanos, a solução hierarquizante para a solução de conflitos normativos não é absoluta. Diga-se o mesmo sobre os critérios temporal e de especialidade. Os critérios usuais de solução de antinomia cedem ao critério pro persona e às interpretações jurisprudenciais internacionais e nacionais vinculantes aos Poderes de Estado. Restringindo-se ao status, desde que uma norma de hierarquia inferior seja mais benéfica ou menos prejudicial ao interesse do ser humano sujeito à sua incidência ou irradiação, ela deverá prevalecer perante normas que sejam de hierarquia superior. $\mathrm{O}$ critério hierárquico é flexível na pirâmide de normas: se a priori um tratado está no ápice do sistema, isso não impede que em algumas hipóteses um tratado de direitos humanos ceda em face da Constituição ou mesmo de normas legais ou atos administrativos, desde que sua norma não seja a mais favorável ou menos prejudicial. Mas o princípio pro persona 
ou pro homine, previsto em diversos tratados internacionais, entre eles no art. 29 do Pacto de São José da Costa Rica, não serve apenas para solução de conflitos insanáveis entre normas. Ele além disso serve de guia hermenêutico. Orienta o intérprete a proceder na interpretação ou aplicação da norma mais ampla para reconhecer direitos, e a proceder na interpretação e aplicação mais restrita para limitá-los. E mesmo que haja dificuldades práticas na aplicação do princípio pro persona, por exemplo em definir qual seria a melhor norma ou a menos pior, isso não impede que por meio dos métodos usuais de interpretação jurídica e argumentação chegue-se a soluções ótimas ou tendentes ao ótimo. O princípio pro persona, aliás, é plenamente compatível com a técnica da ponderação, cujo maior mérito é conciliar princípios a uma primeira vista antagônicos no caso concreto. Em suma, o princípio pro persona tem a virtude de acrescentar um elemento menos abstrato de resolução no processo de decisão, qual seja, o privilégio da defesa da pessoa humana mesmo quando estejam sendo sopesados direitos com conteúdos inicialmente inconciliáveis.

O reconhecimento da supraconstitucionalidade não minora o papel institucional da Constituição nem sua força normativa. A Lei Fundamental ainda é o documento constituinte da sociedade política e jurídica do Estado brasileiro, que preserva sua soberania no esquema de organização, distribuição e exercício de competências nela definidos. Os direitos fundamentais e seu regime jurídico peculiar continuam intactos, do mesmo modo que o conjunto cultural e normativo nacional plasmado no bloco de constitucionalidade de cada país. Assumir a hierarquia supraconstitucional relativa apenas termina com esquemas teóricos ultrapassados sobre o conceito de soberania nacional, uma opção encampada pelo próprio constituinte em 1988. Diferentemente do que se poderia pensar, outorgar prevalência aos tratados de direitos humanos ou situá-los em patamar hierárquico superior não ultraja a normatividade constitucional construída a duras penas desde 1988 e ainda em processo de edificação. Ao contrário, a supraconstitucionalidade dos tratados é compatível com os desígnios do constituinte originário que, como visto, determinou a prevalência dos direitos humanos nas relações internacionais e a inclusão preferencial de direitos humanos no catálogo de direitos com regime jurídico diferenciado de aplicabilidade imediata. Foi o constituinte que, afinado com as tendências globalizantes e supranacionais do Direito Internacional dos Direitos Humanos, relativizou em matéria de direitos humanos a soberania estatal e optou por patamares protetivos mínimos da pessoa humana e do meio ambiente. Esses patamares são definidos em consenso pelas nações em compromissos internacionais e interpretados por Cortes internacionais com competência consultiva e contenciosa voluntariamente reconhecida pelo Estado brasileiro. No mais, prevalece o posicionamento interno naquilo em que a Constituição e a interpretação dos tribunais brasileiros forem mais benéficas para o ser humano. Nesse quesito, a teoria dos diálogos jurisdicionais serve de apoio para afastar teses que façam prevalecer a todo custo a posição de 
Cortes externas ou normas internacionais não condizentes com a finalidade protetiva do Direito Internacional dos Direitos Humanos.

\section{REFERÊNCIAS}

ALEXY, Robert. Teoria dos Direitos Fundamentais. Trad. Virgílio Afonso da Silva. São Paulo: MaIheiros. 2015.

ALIANAK, Raquel Cynthia. El renovado Derecho Administrativo, a la luz del control de convencionalidad. Revista Eurolatinoamericana de Derecho Administrativo, Santa Fe, vol. 2, n. 1, p. 283-300, ene./jun. 2015.

BACELLAR FILHO, Romeu Felipe. Reflexões sobre Direito Administrativo. Belo Horizonte: Fórum, 2009.

BOGDANDY, Armin von. Ius Constitucionale Commune na América Latina. Uma reflexão sobre um constitucionalismo transformador. Revista de Direito Administrativo, Rio de Janeiro, v. 269, p. 33-66, maio/ago. 2015.

BRASIL, Supremo Tribunal Federal. Agravo Regimental em Carta Rogatória n. 8.279-4-Argentina. Tribunal Pleno. Relator Min. Celso de Mello. Julgado em 17/06/1998. Publicado em 10/08/2000.

BRASIL. Supremo Tribunal Federal. Habeas Corpus n. 72.131-RJ. Tribunal Pleno. Relator para acórdão Min. Moreira Alves. Julgamento em 23/11/1995. Publicado em 28/11/1995.

BRASIL. Supremo Tribunal Federal. Recurso Extraordinário n. 80.004-SE. Tribunal Pleno. Relator Min. Xavier de Albuquerque. Julgamento em 01/06/1977. Publicado em 29/12/1977.

CAMPOS, Germán J. Bidart. Teoría general de los derechos humanos. Buenos Aires: Editorial Astrea de Alfredo y Ricardo Depalma, 1991.

CASSAGNE, Juan Carlos. Los nuevos derechos y garantías. Revista de Investigações Constitucionais, Curitiba, vol. 3, n. 1, p. 59-108, jan./abr. 2016.

CLÈVE, Clèmerson Merlin. Para uma dogmática constitucional emancipatória. Belo Horizonte: Fórum, 2012.

CORTE INTERAMERICANA DE DIREITOS HUMANOS. Caso A Última Tentação de Cristo vs. Chile. Publicado em 5 fev. 2001.

CORTE INTERAMERICANA DE DIREITOS HUMANOS. Caso Boyce e outros vs. Barbados. Publicado em 20 nov. 2007.

CORTE INTERAMERICANA DE DIREITOS HUMANOS. Caso Caesar vs. Trinidade e Tobago. Publicado em 11 mar. 2005.

CORTE INTERAMERICANA DE DIREITOS HUMANOS. Caso Dacosta Cadogan vs. Barbados. Publicado em 24 set. 2009. 
CORTE INTERAMERICANA DE DIREITOS HUMANOS. Caso Hilaire, Constantine e Benjamin e outros vs. Trinidade e Tobago. Publicado em 27 nov. 2003.

DWORKIN, Ronald. Levando os direitos a sério. São Paulo: Martins Fontes, 2002.

EMERIQUE, Lilian Balmant; GUERRA, Sidney. A incorporação dos tratados internacionais de direitos humanos na ordem jurídica brasileira. Revista Jurídica, Brasília, v. 10, n. 90, p.1-34, abr./maio, 2008.

FACHIN, Luiz Edson. Notas para um ensaio sobre a posição jurídica dos tratados internacionais de direitos humanos no Brasil após a reforma constitucional. In: PRONER, Carol; CORREAS, Oscar (Coord.). Teoria crítica dos direitos humanos: in memoriam Joaquín Herrera Flores. Belo Horizonte: Fórum, 2011.

FERREIRA, Rafael Fonseca; LIMBERGER, Têmis Um diálogo sobre a autonomia da constituição e os direitos humanos: aproximações hermenêuticas a noção de bloco de constitucionalidade. Revista de Investigações Constitucionais, Curitiba, vol. 5, n. 1, p. 317-330, jan./abr. 2018.

FERREIRA FILHO, Manoel Gonçalves. Direitos humanos fundamentais. 14. ed. São Paulo: Saraiva, 2012.

FRAGA, Mirtô. A obrigatoriedade do tratado na ordem interna. Revista de Informação Legislativa, Brasília, a. 41, n. 162, p. 311-328, abr./jun. 2004.

FRIEDRICH, Tatyana Scheila. As normas imperativas do Direito Internacional Público: Jus Cogens. Belo Horizonte: Fórum, 2004.

GALINDO, George Rodrigo Bandeira. O $\S 3^{\circ}$ do art. $5^{\circ}$ da Constituição Federal: um retrocesso para a proteção internacional dos direitos humanos no Brasil. Revista do Instituto Brasileiro de Direitos Humanos, Fortaleza, v. 6, n. 6, p. 121-131, 2005.

GALINDO, George Rodrigo Bandeira. Tratados Internacionais de Direitos Humanos e Constituição Brasileira. Belo Horizonte: Del Rey, 2002.

GANHO, Luciano Giambarresi; BRANDT, Rafael Weiss. Organização política regional na América-Latina: necessidade específica ou escolha caprichosa. Revista de Direito Econômico e Socioambiental, Curitiba, v. 5, n. 2, p. 113-135, jul./dez. 2014.

GATTI, Franco. La doctrina del "margen de apreciación nacional" y la Administración Pública: horizontes y limitaciones del control de convencionalidad. Revista Eurolatinoamericana de Derecho Administrativo, Santa Fe, vol. 3, n. 1, p. 19-32, ene./jun. 2016.

GOMES, Eduardo Biacchi. Controle de convencionalidade nos processos de integração - democracia e MERCOSUL (a construção de uma tese). A\&C - Revista de Direito Administrativo \& Constitucional, Belo Horizonte, a. 13, n. 52, p. 231-245, abr./jun. 2013.

GOMES, Luiz Flávio; MAZZUOLI, Valerio de Oliveira. Direito Supraconstitucional: do absolutismo ao Estado Constitucional e Humanista de Direito. 2. ed. São Paulo: Revista dos Tribunais, 2013. 
GONZÁLEZ MORAS, Juan M. La internacionalización del Derecho Administrativo argentino. Revista Argentina del Régimen de la Administración Pública, a. XXIX, n. 348, Buenos Aires, Ediciones RAP, p. 15-53, set. 2007.

GORDILLO, Agustín Alberto et al. Derechos humanos. 6. ed. Buenos Aires: Fundación de Derecho Administrativo, 2007.

HACHEM, Daniel Wunder. Princípio constitucional da supremacia do interesse público. Belo Horizonte: Fórum, 2011.

HACHEM, Daniel Wunder. Tutela administrativa efetiva dos direitos fundamentais sociais: por uma implementação espontânea, integral e igualitária. Curitiba, 2014. 604 p. Tese (Doutorado em Direito) - Universidade Federal do Paraná, Setor de Ciências Jurídicas, Programa de Pós-Graduação em Direito, Curitiba, 2014.

HACHEM, Daniel Wunder; PETHECHUST, Eloi. O direito humano à comunicação prévia e pormenorizada das acusações nos processos administrativos: O desprezo do Superior Tribunal de Justiça ao Pacto de San José da Costa Rica e à Corte Interamericana de Direitos Humanos. Revista de Direito Internacional, Brasília, v. 12, n. 2, p. 589-610, 2015.

HENDERSON, Humberto. Los tratados internacionales de derechos humanos en el orden interno: la importancia del princípio pro homine. Revista IIDH, San José, v. 39, p. 71-99, 2004.

HERNÁNDEZ, Jesús M. Casal. El constitucionalismo latinoamericano y la oleada de reformas constitucionales en la región andina. Rechtsgeschichte, Munique, v. 16, p. 212-241, 2010.

HESPANHA, Antonio Manuel. O caleidoscópio do Direito: o Direito e a justiça nos dias e no mundo de hoje. 2. ed. Coimbra: Almedina, 2009.

HESPANHA, Antonio Manuel. Pluralismo jurídico e direito democrático. São Paulo: Annablume, 2013.

HILDEBRANDO, Accioly; SILVA, Geraldo E. do Nascimento e; CASELLA, Paulo Borba. Manual de Direito Internacional Público. 21. ed. São Paulo: Saraiva, 2014.

KNOP, Karen. Here and there: International law in domestic courts. New York University Journal of International Law and Politics, New York. v. 32. n. 2, p. 501-535, 2000.

LAFER, Celso. A Internacionalização dos Direitos Humanos: constituição, racismo e relações internacionais. Barueri: Manole, 2005.

LASCALA, Maria Carolina Florentino. A relativização da soberania em prol dos direitos humanos. Revista de Direito Público, Londrina, v. 6, n. 2, p. 87-102, ago./set. 2011.

LEAL, Mônia Clarissa Henning. Corte Interamericana de Direitos Humanos e jurisdição constitucional: judicialização e ativismo judicial em face da proteção dos direitos humanos e fundamentais? Revista de Investigações Constitucionais, Curitiba, v. 1, n. 3, p. 123-140, set./dez. 2014. 
LEAL, Mônia Clarissa Henning; ALVES, Felipe Dalenogare. O controle de convencionalidade e o Judiciário brasileiro: a sua aplicação pelo Tribunal Superior do Trabalho como forma de proteger a dignidade da mão-de-obra (vedação de terceirização de atividade-fim) no case Carneiro Távora v. Telemar Norte Leste e Conta. Revista de Investigações Constitucionais, Curitiba, v. 4, n.1, p. 109-129, jan./abr. 2017.

MALISKA, Marcos Augusto. Constituição e cooperação normativa no plano internacional: reflexões sobre o voto do Ministro Gilmar Mendes no Recurso Extraordinário n. 466.343-1. Espaço Jurídico, Joaçaba, v. 9, n. 2, p. 113-124, jul./dez. 2008.

MARTINS, Leonardo; MOREIRA, Thiago Oliveira. Controle de convencionalidade de atos do Poder Público: concorrência ou hierarquia em face do controle de constitucionalidade. In: PAGLIARINI, Alexandre Coutinho; DIMOULIS, Dimitri (Coord.). Direito Constitucional e Internacional dos Direitos Humanos. Belo Horizonte: Fórum, 2012.

MAZZUOLI, Valerio de Oliveira. Teoria geral do controle de convencionalidade no direito brasileiro. Revista de Informação Legislativa, Brasília, a. 46, n. 181, p. 113-139, jan./mar. 2009.

MAZZUOLI, Valerio; GOMES, Luiz Flávio. Tratados internacionais: valor legal, supralegal, constitucional ou supraconstitucional? Revista de Direito, v. 12, n. 15, p. 7-20, 2009.

MELLO, Celso Antônio Bandeira de. Curso de Direito Administrativo. 33. ed. São Paulo: Malheiros, 2016.

MELLO, Celso Duvivier de Albuquerque. Curso de Direito Internacional Público. 15. ed. v. I. Rio de Janeiro: Renovar, 2004.

MELLO, Celso Duvivier de Albuquerque. O $\$ 2^{\circ}$ do art. $5^{\circ}$ da Constituição Federal. In: TORRES, Ricardo Lobo (Org.). Teoria dos Direitos Fundamentais. 2. ed. Rio de Janeiro: Renovar, 2001.

MELO, Juliane Andréa de Mendes Hey; BONATO, Ariadne da Silveira. Cláusula de abertura dos direitos fundamentais e status hierárquico dos tratados internacionais de direitos humanos. $\mathbf{R e}$ vista Direitos Humanos e Democracia, ljuí, a. 5, n. 9, p. 274-305, jan./jun. 2017.

MENDES, Gilmar Ferreira. A supralegalidade dos tratados internacionais de direitos humanos e a prisão civil do depositário infiel no Brasil. In: BOGDANDY, Armin Von; PIOVESAN, Flávia; ANTONIAZZI, Mariela Morales (Coord.). Direitos humanos, democracia e integração jurídica: avançando no diálogo constitucional e regional. Rio de Janeiro: Lumen Juris, 2011.

MORAES, Alexandre de. Direitos humanos fundamentais: teoria geral, comentários aos arts. $1^{\circ}$ a $5^{\circ}$ da Constituição da República Federativa do Brasil, doutrina e jurisprudência. 9. ed. São Paulo: Atlas, 2011.

MOREIRA, Thiago Oliveira. A aplicação dos tratados internacionais de direitos humanos pela jurisdição brasileira. Natal: EDUFRN, 2015. 
NEVES, Marcelo. (Não) Solucionando problemas constitucionais: transconstitucionalismo além de colisões. Lua Nova, São Paulo, v. 93, p. 201-232, 2014.

NEVES, Marcelo. Transconstitucionalismo. São Paulo: Martins Fontes, 2009.

NEVES, Marcelo. Transconstitucionalismo: breves considerações com especial referência à experiência Latino Americana. In: ANTONIAZZI, Mariela Morales; BOGDANDY, Armin Von; PIOVESAN, Flávia (Coords.). Direitos humanos, democracia e integração jurídica: avançando no diálogo constitucional e regional. Rio de Janeiro: Lumen luris, 2011.

OLIVEIRA, Douglas Henrique de; TACLA, Silvia Regina. Reflexões acerca da possibilidade da Prisão Civil do Depositário Judicial Infiel e tutela jurisdicional efetiva. Revista do Direito Público, Londrina, v.8, n. 1, p.189-214, jan./abr. 2013.

PAGLIARINI, Alexandre Coutinho. Constituição e Direito Internacional: cedências possíveis no Brasil e no mundo globalizado. Rio de Janeiro: Forense, 2004.

PAGLIARINI, Alexandre Coutinho. Teoria geral e crítica do Direito Constitucional e Internacional dos Direitos Humanos. In: PAGLIARINI, Alexandre Coutinho; DIMOULIS, Dimitri (Coord.). Direito Constitucional e Internacional dos Direitos Humanos. Belo Horizonte: Fórum, 2012.

PEREIRA, André Gonçalves; QUADROS, Fausto de. Manual de Direito Internacional Público. 3. ed. Coimbra: Almedina, 1993.

PIOVESAN, Flávia. Direitos humanos e Justiça Internacional. 5. ed. São Paulo: Saraiva, 2014.

PIOVESAN, Flávia. Direitos humanos e o Direito Constitucional internacional. 15. ed. São Paulo: Saraiva, 2015.

RAMOS, André de Carvalho. Curso de Direitos Humanos. 2. ed. São Paulo: Saraiva, 2015.

RAMOS, André de Carvalho. Pluralidade das ordens jurídicas: uma nova perspectiva na relação entre o Direito Internacional e o Direito Constitucional. Revista da Faculdade de Direito da Universidade de São Paulo, São Paulo, v. 106/107, p. 497-524, jan./dez. 2011/2012.

RANGEL, Vicente Marotta. Direito e relações internacionais. 5. ed. São Paulo: Revista dos Tribunais, 1997.

RODRIGUES, Maurício Andreiuolo. Os tratados internacionais de proteção dos direitos humanos e a Constituição. In: TORRES, Ricardo Lobo (Org.). Teoria dos Direitos Fundamentais. 2. ed. Rio de Janeiro: Renovar, 2001. p. 157-195.

SALAZAR MUÑOZ, Rodrigo. Los derechos humanos en México: un reto impostergable. Revista de Investigações Constitucionais, Curitiba, vol. 3, n. 1, p. 145-168, jan./abr. 2016.

SANTOFIMIO GAMBOA, Jaime Orlando. El concepto de convencionalidad: vicisitudes para su construcción sustancial en el sistema interamericano de derechos humanos. Ideas fuerza rectoras. 
Madrid, 2016. 638 f. Tese pós-doutoral. Universidad Carlos III de Madrid; Universidad Externado de Colombia.

SANTOS, Gustavo Ferreira; TEIXEIRA, João Paulo Allain. Diálogo entre tribunais e proteção de direitos humanos: dificuldades e perspectivas. A\&C - Revista de Direito Administrativo \& Constitucional, Belo Horizonte, a. 16, n. 66, p. 267-282, out./dez. 2016.

SARLET, Ingo Wolfgang. Considerações a respeito das relações entre a Constituição Federal de 1988 e os tratados internacionais de direitos humanos. Espaço jurídico, Joaçaba, v. 12, n.2, p. 325-344, jul./dez. 2011.

SCHIER, Paulo Ricardo. Hierarquia Constitucional dos Tratados Internacionais de Direitos Humanos e EC 45 - tese em favor da incidência do tempus regit actum. In: CONGRESSO NACIONAL DO CONPEDI, 14., 2006, Florianópolis. Anais... Florianópolis: Fundação Boiteux, 2006. p. 161. Disponível em: <www.conpedi.org/manaus/arquivos/Anais/Paulo\%20Ricardo\%20Schier.pdf>.

SILVA, Caíque Tomaz Leite da. Do realismo à constitucionalização do direito internacional. Revista do Direito Público, Londrina, v. 9, n. 1, p.135-162, jan./abr. 2014.

SILVA, Caíque Tomaz Leite; OLIVEIRA, Carlos Eduardo Sindona de. O décimo aniversário da emenda 45 e a posição hierárquica dos tratados de direitos humanos. Revista do Direito Público, Londrina, v.11, n. 1, p. 137-162, jan./abr. 2016.

TEIXEIRA, Anderson Vichikesnki. Constitucionalismo transnacional: por uma compreensão pluriversalista do Estado constitucional. Revista de Investigações Constitucionais, Curitiba, v. 3, n. 3, p. 141-166, set./dez. 2016.

TORELLY, Marcelo. Governança transversal dos direitos fundamentais. Rio de Janeiro: Lumen Juris, 2016.

TRINDADE, Antônio Augusto Cançado. A humanização do Direito Internacional. Belo Horizonte: Del Rey, 2006.

TRINDADE, Antônio Augusto Cançado. Tratado de Direito Internacional dos Direitos Humanos. v. I. 2. ed. Porto Alegre: Sergio Antonio Fabris Editor, 2003.

VIEIRA, Gustavo Oliveira; MORAIS, José Luis Bolzan de. A internacionalização do Direito a partir dos diretos humanos - reflexões iniciais para o futuro do constitucionalismo. Revista de Estudos Constitucionais, Hermenêutica e Teoria do Direito (RECHTD), São Leopoldo, v. 4, n. 2, p. 175184, jul./dez. 2012. 